Estudios Constitucionales, Año 8, No 2, 2010, pp. 293 - 358.

ISSN 0718-0195

Centro de Estudios Constitucionales de Chile Universidad de Talca

"La afectación de los derechos constitucionales en el proceso penal acusatorio según

la jurisprudencia del Tribunal Constitucional del Perú en el período 1997-2009”

Hesbert Benavente Chorres

\title{
LA AFECTACIÓN DE LOS DERECHOS CONSTITUCIONALES EN EL PROCESO PENAL ACUSATORIO SEGÚN LA JURISPRUDENCIA DEL TRIBUNAL CONSTITUCIONAL DEL PERÚ EN EL PERÍODO 1997-2009
}

\author{
THE LIMITATION OF CONSTITUTIONAL RIGHTS IN THE SYSTEM \\ ADVERSARY. ANALYSIS OF THE JURISPRUDENCE OF THE CONSTITUTIONAL \\ COURT OF PERU IN THE PERIOD 1997-2009
}

\begin{abstract}
Hesbert Benavente Chorres ${ }^{1}$
Investigador del Centro de Ciencias Jurídicas, Justicia Penal y Seguridad Pública de la Facultad de Derecho de la Universidad Autónoma del Estado de México estudiobenavente@yahoo.com
\end{abstract}

RESUMEN: El presente estudio analiza cómo el ejercicio de los derechos constitucionales a la inviolabilidad del domicilio, la inviolabilidad de las comunicaciones y la libertad personal, en el Perú, puede ser restringido a través de la orden de allanamiento o cateo, la intervención judicial de las comunicaciones y la detención por delito flagrante, respectivamente, y dentro de las reglas del denominado proceso penal acusatorio. En ese sentido, se tomará en cuenta lo establecido tanto en la Constitución como en el Código Procesal Penal del Perú, asi como en aquellas sentencias del Tribunal Constitucional peruano que han tratado este tema.

ABSTRACT: This study examines the limitation of rights constitutional: inviolability of domicile, the inviolability of communications and personal freedom in Peru, through the search warrant, judicial intervention communications and the arrest respectively, in the system adversary. In this regard, take into account the provisions in both the Constitution and the Penal Procedure Code of Peru, as well as in those Peruvian Constitutional Court rulings that have addressed this issue.

PALABRAS ClaVE: Derechos constitucionales. Domicilio. Comunicaciones. Libertad personal. Allanamiento. Detención y Tribunal Constitucional del Perú.

KEY WORDS: Constitutional rights. Address. Communications. Personal liberty. Search warrant. Arrest and Constitutional Court of Peru.

\footnotetext{
${ }^{1}$ Doctorando en Derecho en la Universidad Autónoma del Estado de México, catedrático universitario en la Universidad Autónoma del Estado de México, Universidad de la Amazonia Peruana, investigador del Centro de Ciencias Jurídicas, Justicia Penal y Seguridad Pública de la Facultad de Derecho de la Universidad Autónoma del Estado de México. Artículo recibido el 7 de junio y aprobado el 22 de septiembre de 2010.
} 


\section{INTRODUCCIÓN}

La reforma del proceso penal, esto es, el tránsito de un modelo con orientación a lo inquisitivo a uno de corte acusatorio y adversarial, no solamente conlleva a cambios estructurales, funcionales y normativos en el sistema de justicia penal de una determinada sociedad; sino que implica, además, la generación de conocimiento en torno a los fundamentos, instituciones y dinámica atribuible al citado modelo procesal.

Ahora bien, parte de esta dinámica es la relación derechos constitucionalesproceso penal, donde, en un primer escenario, los derechos constitucionales fungen como un poder jurídico de contención al ius puniendi del Estado, el cual se sirve del proceso penal a fin de aplicar una sanción al responsable de un hecho delictuoso; pero, y como segundo escenario, el mencionado poder jurídico de contención puede verse relajado o debilitado por la manipulación, por parte de los órganos públicos, de los derechos constitucionales, los cuales se convierten en marcos habilitadores - permisivos- del poder punitivo, sin presencia de límites o controles.

Así, el primer escenario mencionado corresponde al denominado Estado constitucional de Derecho; en cambio, el segundo caracteriza al llamado Estado de Policía, cuya constante tensión y relación dialéctica incide, entre otros puntos, en el ámbito de lo punitivo (Zaffaroni, 2009, p. 73).

Ante tal marco dialéctico, el objetivo del presente estudio es analizar la afectación de los derechos constitucionales en el proceso penal peruano de corte acusatorio -adoptado a raíz del Código Procesal Penal de 2004-, tomando en cuenta las decisiones emitidas por el Tribunal Constitucional del Perú, a fin de establecer si los mencionados derechos constituyen o no un poder jurídico de contención al poder punitivo estatal.

En esa inteligencia, se debe tener en cuenta que, al no constituir, el Tribunal Constitucional del Perú, en un órgano de jurisdicción ordinaria, y menos aún, de competencia penal, no se va a encontrar decisiones en torno a todas las materias propias del Derecho penal; por lo que el lector podrá identificar, en el contenido del presente trabajo, el estudio de determinadas - por no decir algunas-instituciones jurídico-penales que han sido trabajados por el Tribunal Constitucional peruano a raíz de la interposición de una demanda de amparo o de hábeas corpus en la que se comunica la afectación de un derecho constitucional sobre la base de un acto emanado por autoridad en el marco de un proceso punitivo.

Igualmente, la selección de casos también obedece a un criterio de delimitación temporal; esto es, se ha tomado las sentencias del Tribunal Constitucional 
del Perú emitidas durante el período 1997-2009; ello se debe a que, durante el citado período de tiempo, se han publicitado las decisiones del citado órgano de jurisdicción constitucional, y de esta manera ha posibilitado su identificación y análisis. En ese orden de ideas, el lector podrá identificar, tanto en las notas de pie de página -que se han empleado exclusivamente para la finalidad que a continuación se expondrá- así como en las referencias bibliográficas, toda la información necesaria para la localización y ubicación de las sentencias examinadas en el presente estudio.

Frente al escenario antes descrito, se ha seleccionado el estudio de los siguientes derechos constitucionales: (1) el derecho a la inviolabilidad del domicilio (2) el derecho a la inviolabilidad de las comunicaciones y (3) el derecho a la libertad personal. Igualmente, para el examen de los mencionados derechos, los vamos a relacionar con las siguientes instituciones propias del proceso penal: (1) el allanamiento (2) la interceptación de las comunicaciones y (3) la detención por flagrancia delictiva, respectivamente.

Finalmente, debemos resaltar que hemos recurrido a la doctrina especializada del Derecho procesal penal, dado que la interpretación realizada por el Tribunal Constitucional del Perú en torno a la afectación de determinados derechos constitucionales a raíz de decisiones tomadas en el marco del proceso penal, solamente podrán ser analizadas cuando, a la par del Derecho constitucional, también se tome en cuenta el Derecho procesal punitivo.

\section{EL DERECHO A LA INVIOLABILIDAD DEL DOMICILIO Y EL ALLANAMIENTO}

La jerarquía constitucional y el grado de protección que rodean al derecho a la inviolabilidad del domicilio nacen, por un lado, de su carácter de derecho fundamental de toda persona humana y, por otro lado, de la supremacía y fuerza normativa de la Constitución, como documento que declara el reconocimiento del citado derecho.

A continuación, analizaremos ambas dimensiones de justificación del carácter constitucional del derecho a la inviolabilidad del domicilio.

\subsection{El carácter fundamental del derecho a la inviolabilidad del domicilio}

En principio, el concepto de derechos fundamentales comprende "tanto los presupuestos éticos como los componentes jurídicos, significando la relevancia moral de una idea que compromete la dignidad humana y sus objetivos de autonomía moral, y también la relevancia jurídica que convierte a los derechos en norma básica material del Ordenamiento, y es instrumento necesario para que 
el individuo desarrolle en la sociedad todas sus potencialidades. Los derechos fundamentales expresan tanto una moralidad básica como una juridicidad básica" (Peces-Barba, 1995, p. 37).

Consecuentemente, si bien el reconocimiento positivo de los derechos fundamentales (comúnmente, en la Norma Fundamental de un ordenamiento) es presupuesto de su exigibilidad como límite al accionar del Estado y de los propios particulares, también lo es su connotación ética y axiológica, en tanto manifiestas concreciones positivas del principio-derecho de dignidad humana, preexistente al orden estatal y proyectado en él como fin supremo de la sociedad y del Estado. ${ }^{2}$

Por su parte, los derechos fundamentales, como objetivo de autonomía moral, y siguiendo a Pérez Luño, sirven para "designar los derechos humanos positivizados a nivel interno, en tanto que la fórmula derechos humanos es la más usual en el plano de las declaraciones y convenciones internacionales" (Pérez, 2003, p. 31).

Por otro lado, y en cuanto al contenido de los derechos fundamentales, Manuel Medina Guerrero, señala que: "en cuanto integrantes del contenido constitucionalmente protegido, cabría distinguir, de un lado, un contenido no esencial, esto es, claudicante ante los límites proporcionados que el legislador establezca a fin de proteger otros derechos o bienes constitucionalmente garantizados y, de otra parte, el contenido esencial, absolutamente intangible para el legislador; y extramuros del contenido constitucionalmente protegido, un contenido adicional formado por aquellas facultades y derechos concretos que el legislador quiera crear impulsado por el mandato genérico de asegurar la plena eficacia de los derechos fundamentales" (Medina, 1996, p. 41).

En ese sentido, todo ámbito constitucionalmente protegido de un derecho fundamental se reconduce en mayor o menor grado a su contenido esencial, pues todo límite al derecho fundamental sólo resulta válido en la medida que el contenido esencial se mantenga incólume.

$\mathrm{Al}$ respecto, la determinación del contenido esencial de los derechos fundamentales no puede efectuarse a priori, es decir, al margen de los principios, los valores y los demás derechos fundamentales que la Constitución reconoce. En efecto, en tanto el contenido esencial de un derecho fundamental es la concreción de las esenciales manifestaciones de los principios y valores que lo informan, su determinación requiere un análisis sistemático de este conjunto de bienes constitucionales, en el que adquiere participación medular el principio-derecho de dignidad humana, al que se reconducen, en última instancia, todos los derechos fundamentales de la persona.

${ }^{2}$ Tribunal Constitucional del Perú. Anicama con Oficina de Normalización Previsional (2005). 
En tal sentido, el contenido esencial de un derecho fundamental y los límites que sobre la base de éste resultan admisibles, forman una unidad (Häberle, 1997, p. 117); por lo que, en la ponderación que resulte necesaria a efectos de determinar la validez de tales límites, cumplen una función vital los principios de interpretación constitucional de "unidad de la Constitución" y de "concordancia práctica”, cuyo principal cometido es optimizar la fuerza normativo-axiológica de la Constitución en su conjunto.

Si bien es cierto que la exactitud de aquello que constituye o no el contenido protegido por parte de un derecho fundamental y, más específicamente, el contenido esencial de dicho derecho, sólo puede ser determinado a la luz de cada caso concreto, no menos cierto es que existen determinadas premisas generales que pueden coadyuvar en su ubicación. Para ello, es preciso tener presente la estructura de todo derecho fundamental.

En ese sentido, y siguiendo a Bernal Pulido, "todo derecho fundamental se estructura como un haz de posiciones y normas, vinculadas interpretativamente a una disposición de derecho fundamental" (Bernal, 2003, p. 76).

De esta forma cabe distinguir entre las disposiciones de derecho fundamental, las normas de derecho fundamental y las posiciones de derecho fundamental.

Las disposiciones de derecho fundamental son los enunciados lingüísticos de la Constitución que reconocen los derechos fundamentales de la persona. Las normas de derecho fundamental son los sentidos interpretativos atribuibles a esas disposiciones. Mientras que las posiciones de derecho fundamental son las exigencias concretas que, al amparo de un determinado sentido interpretativo válidamente atribuible a una disposición de derecho fundamental, se buscan hacer valer frente a una determinada persona o entidad. ${ }^{3}$

Tal como refiere el mismo Bernal Pulido, "las posiciones de derecho fundamental son relaciones jurídicas que (...) presentan una estructura triádica, compuesta por un sujeto activo, un sujeto pasivo y un objeto. El objeto de las posiciones de derecho fundamental es siempre una conducta de acción o de omisión, prescrita por una norma que el sujeto pasivo debe desarrollar en favor del sujeto activo, y sobre cuya ejecución el sujeto activo tiene un derecho, susceptible de ser ejercido sobre el sujeto pasivo" (Bernal, 2003, p. 80).

En esa inteligencia, cabe afirmar que las posiciones de derecho fundamental son los derechos fundamentales en sentido estricto, pues son los concretos atributos que la persona humana ostenta al amparo de las normas (sentidos interpretativos) válidas, derivadas directamente de las disposiciones contenidas en la Constitución que reconocen derechos.

${ }^{3}$ Tribunal Constitucional del Perú. Anicama con Oficina de Normalización Previsional (2005). 
Ahora bien, un atributo de la personalidad del ser humano es la privacía de sus actos y, para ello, cuenta con un espacio físico determinado, denominado domicilio o morada, para el desarrollo de los mismos; ostentando el poder de excluir la intromisión de terceras personas.

En ese sentido, espacio físico, privacía y exclusión de la intromisión -aspectos que serán desarrollados más adelante- caracterizan el derecho a la inviolabilidad de domicilio; en donde, su carácter de derecho fundamental descansa en ser un límite al accionar del Estado y de los propios particulares, como también en su connotación axiológica.

Sin embargo, y como se examinará en los puntos siguientes, este derecho no es absoluto, sino que puede ser restringido por razones de sanidad, grave riesgo, por la comisión de un delito flagrante o por mandato judicial que autorice el ingreso al domicilio de una persona, aun sin su consentimiento.

$\mathrm{Al}$ respecto, el artículo $2^{\circ}$, inciso $9^{\circ}$ de la Constitución Política del Perú ha establecido lo siguiente:

"Toda persona tiene derecho: (...) 9. A la inviolabilidad del domicilio. Nadie puede ingresar en él ni efectuar investigaciones o registros sin autorización de la persona que lo habita o sin mandato judicial, salvo flagrante delito o muy grave peligro de su perpetración. Las excepciones por motivos de sanidad o de grave riesgo son reguladas por la ley".

\subsection{La supremacía y la fuerza normativa de la Constitución} como marco de respeto al derecho a la inviolabilidad del domicilio

Como se sabe, la Constitución, en la medida que contiene normas jurídicas, es fuente del derecho. Al respecto, Francisco Balaguer Callejón comenta que: "La Constitución contiene las normas fundamentales que estructuran el sistema jurídico y que actúan como parámetro de validez del resto de las normas" (Balaguer, 1992, p. 28).

La Constitución es la norma de normas que disciplina los procesos de producción del resto de las normas y, por tanto, la producción misma del orden normativo estatal. El reconocimiento de la Constitución como norma jurídica vinculante y directamente aplicable constituye la premisa básica para que se erija como fuente de Derecho y como fuente de fuentes. Al respecto, el Tribunal Constitucional del Perú señala lo siguiente: “(...) la Constitución es una norma jurídica. En efecto, si expresa la autorrepresentación cultural de un pueblo, y refleja sus aspiraciones como nación, una vez formado el Estado Constitucional de Derecho, ella pasa a ocupar una posición análoga a la que ocupaba su creador. En buena cuenta, en el Estado Constitucional de Derecho, el status de Poder Constituyente, es decir, 
la representación del pueblo políticamente soberano, lo asumirá la Constitución, que de esta forma pasará a convertirse en la norma jurídicamente suprema". ${ }^{4}$

Con relación a la Constitución como fuente de nuestro "Derecho nacional", debe remarcarse que constituye el fundamento de todo el "orden jurídico" y la más importante fuente normativa. Al respecto, Balaguer apunta que: "La Constitución es la fuente suprema dentro del ordenamiento, que conforma el orden jurídico fundamental del Estado y de la sociedad" (Balaguer, 1992, p. 28).

En cuanto norma suprema del ordenamiento, la Constitución prevalece sobre todas las demás y en ese sentido condiciona el resto de las normas, por cuanto determina la invalidez de aquellas que formal o materialmente contradigan las prescripciones constitucionales (Betegon, et al. 1997, p. 205).

Es por ello que la Constitución termina convirtiéndose en el fundamento de validez de todo el ordenamiento instituido por ella. De manera que una vez que entra en vigencia, cualquier producción normativa de la Federación, las Entidades Federativas y el Distrito Federal e, inclusive, los actos y comportamientos de los particulares, deben guardarle lealtad y fidelidad. Ciertamente, no se trata sólo de una adhesión y apoyo que pueda ser medido o evaluado en el plano de la moral o la ética, sino también de una exigencia de coherencia y conformidad de la que es posible extraer consecuencias jurídicas. La infidelidad constitucional, en efecto, acarrea la posibilidad de declarar la invalidez de toda norma o acto, cualquiera sea su origen, según los alcances que el mismo ordenamiento constitucional haya previsto.

Por otro lado, la Constitución contiene un conjunto de normas supremas porque éstas irradian y esparcen los principios, valores y contenidos a todas las demás pautas jurídicas restantes. En esa perspectiva, el principio de jerarquía deviene en el canon estructurado del ordenamiento estatal.

El principio de jerarquía implica el sometimiento de los poderes públicos a la Constitución y al resto de normas jurídicas. Consecuentemente, como bien afirma Requena López, "es la imposición de un modo de organizar las normas vigentes en un Estado, consistente en hacer depender la validez de unas sobre otras. Así, una norma es jerárquicamente superior a otra cuando la validez de ésta depende de aquélla" (Requena, 2004, p. 133).

En ese sentido, la doctrina ha identificado el denominado principio de la supremacía de la Constitución, el cual supone una normatividad supra -la Constitución- encargada de consignar la regulación normativa básica de la cual emana la validez de todo el ordenamiento legal de la sociedad política.

\footnotetext{
${ }^{4}$ Tribunal Constitucional del Perú. Borea con Congreso de la República del Perú (2003).
} 
La Constitución es una especie de súper ley, de norma normarum, que ocupa el vértice de la pirámide normativa.

Por otro lado, se puede afirmar la fuerza normativa de la Constitución, la cual implica a su vez: i) una fuerza activa, entendida como aquella capacidad para innovar el ordenamiento jurídico, pues a partir de ella existe una nueva orientación normativa en el sistema de fuentes del ordenamiento jurídico, derogando expresa o implícitamente aquellas normas jurídicas infraconstitucionales que resulten incompatibles con ella (en las que precisamente se produce un supuesto de inconstitucionalidad sobrevenida); y ii) una fuerza pasiva, entendida como aquella capacidad de resistencia frente a normas infraconstitucionales que pretendan contravenir sus contenidos.

Ahora bien, y retomando el tema materia del presente acápite, la Constitución Política del Perú consagra el derecho a la inviolabilidad del domicilio en el artículo 2.9, prohibiendo la entrada o registro sin el consentimiento del titular o resolución judicial, salvo en casos de flagrante delito, peligro inminente de la perpetración de un delito o por razones de sanidad o grave riesgo, este derecho fundamental está reconocido también en los artículos 12 de la Declaración Universal de los Derechos Humanos y 17 del Pacto Internacional de Derecho Civiles y Políticos.

En esa inteligencia, la protección del mencionado derecho surge a raíz de su reconocimiento constitucional y, por extensión, a la supremacía y fuerza normativa que presenta la Carta Magna y que hemos hecho referencia en los párrafos anteriores.

\subsection{El domicilio como objeto de protección}

Los artículos 33 al 38 del Código Civil del Perú de 1984 establecen una serie de definiciones y reglas en torno al domicilio. Así, el artículo 33 del citado cuerpo de leyes precisa que el domicilio se constituye por la residencia habitual de la persona en un lugar.

Sin embargo, el Tribunal Constitucional peruano ha considerado que el concepto civilista de domicilio no es aplicable al ámbito constitucional. En esa inteligencia, el máximo intérprete de la Constitución ha indicado lo siguiente: "La definición constitucional de domicilio no puede ser entendida en los mismos términos que el Código Civil ha regulado esta institución. Como dice Bidart Campos, en el Derecho Constitucional el domicilio es entendido como la "morada destinada a la habitación y al desenvolvimiento de la libertad personal en lo concerniente a la vida privada, ya sea cerrada o abierta parcialmente, móvil o inmóvil, de uso permanente o transitorio". Es decir, la institución del domicilio en términos constitucionales debe ser entendida de manera amplia; por ejemplo, 
la habitación de un hotel constituye domicilio, la oficina particular donde una persona ejerce su profesión debe ser entendida como domicilio".5

$\mathrm{Al}$ respecto, Marchal Escalona define el domicilio, desde el punto de vista constitucional, como "todo espacio cerrado al servicio de una persona, en el que en un momento desarrolla su vida íntima, su privacidad, y del que puede excluir a terceros" (Marchal, 2003, p. 149).

Como se puede observar, el concepto de domicilio, en el ámbito constitucional, está vinculado con la noción de morada y la posibilidad que la persona, en la misma, ejerza otros derechos constitucionales conexos y excluya la intromisión de terceros. Es decir, es una visión amplia, ${ }^{6}$ donde el domicilio es aquel espacio en el cual un individuo vive sin estar sujeto necesariamente a los usos y convenciones sociales y ejerce su libertad más íntima.

Así, para los juristas españoles Queralt y Jiménez Quintana, el domicilio es “el espacio físico constante, separado por voluntad de su morador del resto del espacio físico y en el que dicha persona vive sin estar sujeta necesariamente a los usos y convenciones sociales; siendo sus notas esenciales: a) lugar separado del exterior de forma inequívoca, y b) al mismo tiempo es el lugar donde la persona puede actuar sin intromisión alguna, mientras sus vivencias no trasciendan perjudicialmente al exterior -es lo que se llama la intimidad" (Queralt y Jiménez, 1987, p. 96).

$\mathrm{Al}$ respecto, el Tribunal Constitucional peruano ha precisado lo siguiente:

"En ese sentido, también cabe señalar que coadyuvan a la configuración del citado domicilio constitucional algunos elementos, a saber:

i) El Elemento Físico: El domicilio es el espacio en el cual la persona vive sin estar sujeta a condiciones de comportamiento y en el cual ejerce su libertad más intima.

ii) El Elemento Psicológico: Supone la intención personal de habitar un lugar como morada, sea de manera permanente o de manera transitoria, aun cuando dicho lugar no reúna las condiciones minimas para ello. Según la concepción del domicilio constitucional se exige habitación, pero no necesariamente ésta debe estar caracterizada por la continuidad. iii) El Elemento Autoprotector: Está referido a la exclusión de terceros del lugar destinado a la morada".

De la anterior cita se desprende que para el Tribunal Constitucional del Perú no se requiere de habitualidad; por lo que, se considera morada: la habitación de un hotel o pensión, choza, caseta, tienda de campaña, cueva, etc., siendo indi-

\footnotetext{
${ }^{5}$ Tribunal Constitucional del Perú. Bazán con Sala Penal de la Corte Superior de Justicia de Cañete (2008).

${ }^{6}$ Cualquier lugar cerrado en el que puede transcurrir la vida privada, individual o familiar o lo que es lo mismo, que sirva de habitáculo o de morada.

${ }^{7}$ Tribunal Constitucional del Perú. Bazán con Sala Penal de la Corte Superior de Justicia de Cañete (2008).
} 
ferente que se permanezca unas horas o varios días. En esa inteligencia, y como indican Queralt y Jiménez, "si el domicilio es el lugar donde radica la intimidad de la persona, no hay razón para excluir de tal denominación a las habitaciones hoteleras y, forzando los hechos, quien no tuviera domicilio habitual y residiera exclusivamente en hoteles carecería del derecho a la inviolabilidad del domicilio" (Queralt y Jiménez, 1987, p. 98).

No obstante, y recurriendo a la jurisprudencia del Tribunal Supremo español, el cual ha señalado que "no existe violación del derecho fundamental a la inviolabilidad del domicilio cuando la ocupación de la droga se produce como consecuencia de la limpieza de una habitación, realizada por la empleada de un hotel, después de que el acusado hubiese sido expulsado del establecimiento por formar parte de un grupo que había provocado un fuerte escándalo, resaltando que la tutela constitucional a los domicilios ocasionales es plenamente compatible con la legitimidad de intervenciones como las derivadas de la limpieza de las habitaciones, tácitamente consentidas porque forman parte del régimen de ocupación habitual de los alojamientos hoteleros". ${ }^{8}$

Finalmente, y de acuerdo con lo señalado en los párrafos anteriores, no constituyen domicilio (Alonso, 2003, p. 45):

1. Almacenes, locales comerciales, fábricas y establecimientos públicos.- Así el Tribunal Supremo español, en sentencia del 24 de septiembre de 1990, ha establecido que el lugar en que se llevó a efecto la diligencia de entrada y registro era un almacén, es decir, un lugar reputado público, por tratarse de lugar cerrado que no constituye domicilio de un particular, lo cual no puede carecer de importancia a la hora de valorar la posible trascendencia de las irregularidades cometidas en la práctica de la correspondiente diligencia, por cuanto, la protección constitucional de la inviolabilidad alcanza exclusivamente al domicilio de la personas.

2. Cabina de un camión. - No existe violación del derecho a la inviolabilidad del domicilio, por cuanto la cabina de un camión no puede tener la protección constitucional dispensada al domicilio, con independencia de que en ella haya podido dormir ocasionalmente el imputado, situación que igualmente puede hacerse -y de hecho se hace- en otro tipo de vehiculos, como los automóviles de turismo.

3. Casa abandonada.- Siguiendo una vez más al Tribunal Supremo español, en sentencia del 15 de octubre de 1995, se ha precisado que el piso en que las Fuerzas Policiales ocuparon la heroina y cocaina que el factum concreta no constituye morada de persona alguna, ya que en el mismo, sin titular bien concretado y determinado, no vive nadie, no existen en el mismo las camas, muebles y útiles precisos para llevar a cabo vida personal o familiar

\footnotetext{
${ }^{8}$ Sala de lo Penal del Tribunal Supremo de España. José Pablo con Audiencia Provincial de San Sebastián (1995).
} 
como normalmente se entiende y se encuentra prácticamente abandonado, utilizándose solamente por la acusada recurrente para la venta de droga. Por ello no puede considerarse morada de nadie y no puede extenderse al mismo la protección constitucional, ni serle de aplicación las normas procesales garantizadoras de la inviolabilidad domiciliaria.

4. Celdas de los establecimientos penitenciarios.- Las celdas de los internos situadas en instituciones penitenciarias son de aquellos edificios o lugares cerrados que no constituyen domicilio y si edificios públicos, para entrar en los cuales no es preciso resolución judicial mediante auto motivado, sino que, basta con observar lo dispuesto en la Ley de Ejecución Penal y en los reglamentos existentes en el ámbito penitenciario.

\subsection{Diligencia de entrada y registro en un domicilio (allanamiento o cateo)}

El Tribunal Constitucional peruano ha señalado la restricción en el ejercicio del derecho a la inviolabilidad del domicilio, en los siguientes términos: "Ahora bien, nuestra Constitución ha tutelado el derecho individual que tiene toda persona a la 'libertad de domicilio' a través de la garantía de 'inviolabilidad' y, en ese sentido, ha establecido que los terceros, sean particulares o agentes públicos, en principio, están prohibidos de penetrar el ámbito domiciliario donde habita una persona, salvo que medie el consentimiento de ésta, exista una autorización judicial, se haya configurado una situación de flagrancia delictiva o el peligro inminente de la perpetración de un hecho ilícito sea una realidad. Asimismo, la norma constitucional ha regulado dos supuestos de entrada legítima, como son las razones de sanidad o de grave riesgo".

En esa inteligencia, vamos a resaltar el caso de la diligencia de entrada y registro en un domicilio por mandato judicial, conocida también como allanamiento.

En efecto, esta diligencia es entendida como aquella que, limitando las garantías de libertad individual respecto de los lugares cerrados, tiene por objeto la búsqueda en los mismos de los efectos, instrumentos y objetos del delito, o el hallazgo del propio delincuente.

Para Alicia de Peray estamos ante una típica diligencia de investigación que podrá tener naturaleza policial -en los casos de flagrancia delictiva- o bien judicial; presentando similitudes con la diligencia de inspección judicial (De Peray, 2006, p. 159); pudiendo tener valor probatorio -como prueba documentada-, de acuerdo con lo señalado en el artículo 383, numeral 1), letra e) del Código Procesal Penal peruano.

\footnotetext{
${ }^{9}$ Tribunal Constitucional del Perú. Bazán con Sala Penal de la Corte Superior de Justicia de Cañete (2008).
} 
$\mathrm{Al}$ respecto, Gimeno Sendra enumera las siguientes notas características de la referida diligencia:

"a) Se trata de un acto que, por imperativo constitucional y de sus normas integradoras, está sometido al principio de exclusividad jurisdiccional, sin que pueda la Administración, a través de la autotutela incidir en este derecho constitucional. La competencia exclusiva la ostentará el Juez competente, sin perjuicio de que, en determinados supuestos taxativos y excepcionales, pueda la Policía restringir el ejercicio de este derecho.

b) Su objeto material lo constituye cualquier lugar cerrado en el que se ejercita o puede resultar afectado el derecho a la intimidad del ciudadano. Estando dirigida la Constitución a tutelar el derecho a la intimidad personal y familiar del individuo y constituyendo la inviolabilidad del domicilio la principal garantía para proteger este derecho fundamental, es evidente que la diligencia de entrada ha de estar orientada a garantizar este derecho fundamental, sin perjuicio de que el ordenamiento proteja también otros bienes constitucionales o incluso ordinarios -el secreto profesional, industrial, etc.- fundamentalmente a través de las oportunas entradas especiales.

c) $\mathrm{Al}$ incidir en el ámbito de un derecho fundamental, la diligencia de entrada ha de estar sometida al principio de proporcionalidad. Su adopción ha de revestir, pues, carácter indispensable para obtener el fin perseguido. Habrá de disponerse normalmente mediante resolución motivada y en la forma que menos perjudique al imputado.

d) La diligencia de entrada no constituye acto de prueba alguno, ni siquiera de investigación. Se trata de un acto de investigación indirecto, porque, en sí misma considerada, no tiene por objeto la determinación del hecho o la participación de su autor, sino que es un medio necesario para la práctica de una detención o la realización de un registro. Teleológicamente está, pues, destinada, bien a la adopción de una medida cautelar penal, bien a asegurar determinadas fuentes de prueba, sin embargo, y como veremos al final de este apartado que en Perú sí es posible de dotar de valor probatorio al allanamiento" (Gimeno, et al. 1997, pp. 437-438).

Asimismo, conviene precisar, siguiendo a Rodríguez Sol, que "la entrada y el registro son diligencias conceptualmente distintas. El registro presupone una entrada previa, pero la entrada no siempre se realiza con el fin de practicar un registro, por ejemplo, la entrada puede tener por objeto únicamente la detención del delincuente" (Rodríguez, 1998, p. 05).

Por otro lado, esta diligencia, cuando no opera algún supuesto de flagrancia, requiere de solicitud del Ministerio Público al Juez; al respecto, el artículo 214 
del Código Procesal Penal peruano precisa que, fuera de los casos de flagrante delito o de peligro inminente de su perpetración, y siempre que existan motivos razonables para considerar que se oculta el imputado o alguna persona evadida, o que se encuentran bienes delictivos o cosas relevantes para la investigación, el Fiscal solicitará el allanamiento y registro domiciliario de una casa habitación, casa de negocio, en sus dependencias cerradas, o en recinto habitado temporalmente, y de cualquier otro lugar cerrado, siempre que sea previsible que le será negado el ingreso en acto de función a un determinado recinto.

En ese sentido, la solicitud consignará la ubicación concreta del lugar o lugares que habrán de ser registrados, la finalidad específica del allanamiento, las diligencias a practicar, y el tiempo aproximado que durará. Igualmente, los motivos que determinaron el allanamiento sin orden judicial constarán detalladamente en el acta.

Ahora bien, presentada la solicitud y si el Juez lo considera pertinente emitirá auto motivado donde autoriza el allanamiento. En nuestra opinión, ésta debe ser la forma general de entrada y registro, debiendo considerarse las demás posibilidades como excepcionales ante situaciones que, por diversas razones, hacen imposible o gravemente perjudicial para las investigaciones acudir al Juez para solicitar la autorización correspondiente.

En esa inteligencia, y de acuerdo con el artículo 215 del Código Procesal Penal peruano, la resolución autoritativa contendrá: el nombre del Fiscal autorizado, la finalidad específica del allanamiento y, de ser el caso, las medidas de coerción que correspondan, la designación precisa del inmueble que será allanado y registrado, el tiempo máximo de la duración de la diligencia, y el apercibimiento de ley para el caso de resistencia al mandato. La orden tendrá una duración máxima de dos semanas, después de las cuales caduca la autorización, salvo que haya sido expedida por tiempo determinado o para un período determinado, en cuyo caso constarán esos datos.

Esta exigencia responde al hecho que, en la adopción de esta medida restrictiva de un derecho fundamental, que debe acordarse en auto suficientemente motivado; rigiéndole los principios de idoneidad (adecuación a la investigación), necesidad (insustituibilidad por otra menos grave) y proporcionalidad (gravedad del delito investigado) (Rodríguez, et al. 2003, p. 335). Para Beltrán Núñez, "no es preciso que la motivación del auto sea exhaustiva pero debe recoger los suficientes antecedentes de hecho como para que, en juicio de proporcionalidad, pueda resultar adecuada la lesión de un derecho fundamental; igualmente, los fundamentos de derecho deberán razonar sobre esa adecuación y la pertinencia o necesidad de la diligencia” (Beltrán, 1995, p. 1677). 
$\mathrm{Al}$ respecto, recurrimos a una sentencia del Tribunal Supremo español para ilustrar lo anteriormente citado: “... basta con una sospecha objetivada en datos concretos que conduzcan a ella para que la resolución judicial pueda estimarse fundada". ${ }^{10}$

Ante tal contexto, lo recomendable, y siguiendo la pauta del artículo 214 del texto adjetivo peruano, el solicitante expresa la relación circunstanciada y las razones que a su juicio exigen la entrada, poniendo de relieve y enfatizando aquellos aspectos que más le interesan para obtener el oportuno auto y llevar a cabo la diligencia. Resulta de gran importancia este aspecto por cuanto, tratándose de una actividad lesiva de derechos individuales, debe exigirse un alto cumplimiento de garantías desde el primer momento. A tal efecto, el Juez tiene que disponer del conjunto de elementos que concurran para resolver, sin que en modo alguno pueda verse mermado o dirigido su conocimiento por la petición ministerial, que en ocasiones no tiene más fundamento que unas simples e infundadas conjeturas o suposiciones, sin que se den indicios suficientes para practicar la entrada (Martínez, 2001, p. 391).

En opinión de Marchal Escalona, la motivación de la solicitud de allanamiento deberá abarcar:

“a) Concreción del hecho investigado, para lo cual será preciso atender a la gravedad del delito cualitativa y cuantitativamente. La infracción debe ser de tal entidad que se convierta per se en título suficiente que aconseje limitar el derecho fundamental a la inviolabilidad domiciliaria.

b) Necesidad de su práctica, es decir, lo que se pretende obtener no debe ser alcanzable por ningún medio menos lesivo que el que se propone, ya que si así fuere deberá realizarse por aquella otra vía.

c) Identificación de la persona sospechosa, con indicación cierta del domicilio donde habita.

d) Indicios racionales que han inducido a tal solicitud" (Marchal, 2003, pp. 157-158).

Por otro lado, y de acuerdo con el artículo 216 del Código Procesal Penal peruano, al iniciarse la diligencia se entregará una copia de la autorización al imputado siempre que se encuentre presente o a quien tenga la disponibilidad actual del lugar, comunicándole la facultad que tiene de hacerse representar o asistir por una persona de su confianza. Si no se encuentran las personas arriba indicadas, la copia se entregará y el aviso se dirigirá a un vecino, a una persona que conviva

${ }^{10}$ Sala de lo Penal del Tribunal Supremo de España. Ministerio Fiscal con Audiencia Provincial de Soria (1999). 
con él, y a falta de ellos, sólo de ser posible, al portero o a quien haga sus veces. La diligencia se circunscribirá a lo autorizado, redactándose acta. Durante su desarrollo se adoptarán las precauciones necesarias para preservar la reputación y el pudor de las personas que se encuentren en el local allanado.

Ahora bien, y como se adelantó en párrafos anteriores, la normatividad dota de valor probatorio al acta de allanamiento. En efecto, el artículo 383, numeral 1), letra e) del Código Procesal Penal peruano, precisa que podrá ser incorporado al juicio para su lectura el acta de allanamiento, por contener diligencia objetiva e irreproducible, siempre y cuando se haya realizado conforme lo señala la ley.

Ello es lo que se le conoce como prueba documentada.

En efecto, la prueba documentada es el conjunto de medios probatorios en la que se analizan las actas o registros de lo desahogado en la audiencia de prueba anticipada, o bien de aquellas declaraciones previas de testigos, peritos o coimputados que, por causas de fuerza mayor o la interferencia del acusado, no puedan concurrir a la audiencia del juicio oral; o bien, las actas de diligencias objetivas e irreproducibles celebradas antes de la audiencia de debate oral, como es el caso del allanamiento.

Asimismo, el procedimiento para la actuación de la prueba documentada es:

1. Que sea dentro de uno de los supuestos que señale la ley. El primer paso gira en torno al hecho que una de las partes solicite el desahogo, como prueba documentada, de alguno de los casos o supuestos señalados en la ley.

Ello, porque el valorar como prueba aquello realizado con anterioridad al juicio oral es una flexibilidad que el sistema acusatorio brinda -para hallar la verdad histórica-; pero es una concesión excepcional y debe ser la ley que establezca -bajo un sistema cerrado o numerus clausus - los casos en que procede la lectura o reproducción de tales diligencias como prueba documentada.

2. Que sea solicitada por alguna de las partes y admitida por el Juez o Tribunal del Juicio Oral, o bien por la iniciativa de oficio que la ley permite al juzgador. La prueba documentada surge, no porque las actas, registros, dictámenes o declaraciones obren en un expediente o carpeta, sino porque a solicitud de las partes o de oficio por el juzgador se admitan los tales en calidad de prueba.

3. Una vez admitida, la prueba documentada será leida o reproducida en la audiencia del juicio oral, observándose los principios de inmediación, contradicción y publicidad. El desahogo de las mismas se dará a través de la lectura o reproducción de tales diligencias admitidas como prueba documentada. En primer lugar, la lectura denota la expresión a viva voz y en plena audiencia aquella acta que registra una determinada declaración previa. En segundo lugar, la reproducción consiste en la visualización de un determinado registro (auditivo o visual). Todo 
ello, en presencia de las partes, el juzgador, así como del público asistente en la audiencia del juicio oral.

Ahora bien, este proceder asegura la observancia de los siguientes principios procesales:

a) Con el principio de inmediación, porque el desahogo de la prueba exige el contacto directo entre el Juez o Tribunal del Juicio Oral con el respectivo órgano de prueba. En presencia del juzgador la prueba debe ser actuada o desahogada; si bien, se ve limitada por la ausencia física de aquellos testigos, peritos o imputados, la lectura o reproducción de aquellas actas o registros debe darse ante los sentidos del Juez.

b) Con el principio de contradicción, porque luego de la lectura o reproducción de aquellas actas o registros, las partes tienen el derecho de examinar lo leído o reproducido; formular observaciones y precisiones que permitan contextualizar lo desahogado en aras de sus respectivas teorías del caso.

c) Con el principio de publicidad, porque la lectura o reproducción de aquellas actas o registros debe realizarse en la audiencia del juicio oral, en presencia del público asistente, salvo que se configure alguna excepción prevista en la ley que justifique una sesión privada.

4. Luego de desahogada la prueba documentada, las conclusiones o juicios de valor arribados por el juzgador deben ser contextualizadas con los demás medios probatorios desahogados. La prueba documentada no se valora aisladamente, sino que el Juez o Tribunal del Juicio Oral debe realizar los respectivos juicios de valor hacia todas las pruebas desahogadas en la audiencia del juicio oral; una valoración global, racional y razonable, cuyas conclusiones serán expresadas en la respectiva sentencia o fallo.

Por tanto, si el acta de allanamiento leído en la audiencia del juicio oral cumple con los pasos anteriormente citados, entonces, el mismo tendrá mérito probatorio.

Por otro lado, el artículo 217 del Código Procesal Penal peruano, acota que cuando sea el caso, el Fiscal solicitará que el allanamiento comprenda la detención de personas y también la incautación de bienes que puedan servir como prueba o ser objeto de decomiso. En este caso se hará un inventario en varios ejemplares, uno de los cuales se dejará al responsable del recinto allanado. El allanamiento, si el Fiscal lo decide, podrá comprender el registro personal de las personas presentes o que lleguen, cuando considere que las mismas pueden ocultar bienes delictivos o que se relacionen con el mismo. El Fiscal, asimismo, podrá disponer, consignando los motivos en el acta, que determinada persona no se aleje antes de que la diligencia haya concluido. El transgresor será retenido y conducido nuevamente y en forma coactiva al lugar. 
Finalmente, para aquellos casos donde no es aplicable el Código Procesal Penal del Perú, la realización del allanamiento por orden judicial debe observar lo dispuesto en la Ley $\mathrm{N}^{\circ} 27.379$-modificado por el Decreto Legislativo 988-, las medidas limitativas de derechos o de búsqueda de pruebas que pueden aplicarse durante las primeras diligencias de investigación de aquellos delitos citados en la mencionada ley.

En efecto, la citada ley regula la figura del Allanamiento de inmuebles o lugares cerrados fuera de los casos de flagrante delito o de peligro inminente de su perpetración. Esta medida se da siempre que existan motivos razonables para ello. La medida está destinada a registrar el inmueble y, de ser el caso, a su incautación.

Esta figura puede tener también como finalidad la detención de personas o la realización de las medidas de secuestro o incautación, a fin de asegurar los instrumentos, medios o elementos de convicción, objetos a efectos, provenientes directa o indirectamente de la infracción penal o los instrumentos o medios con que se hubiere ejecutado. La solicitud y: la resolución judicial indicarán expresamente la finalidad del allanamiento y registro.

Cuando el Fiscal, al realizar una inspección en un lugar o en el curso de un allanamiento, encuentra en poder del intervenido o en el lugar objeto de inspección o allanamiento, medios o otros elementos de convicción, efectos provenientes de la infracción penal o los instrumentos o medios con los que se hubiere ejecutado, podrá examinarlos y, de ser el caso, dispondrá su aseguramiento levantando un acta, solicitando de inmediato al Juez se sirva dictar la orden de incautación de los mismos.

El Juez resolverá dentro de 24 horas de recibido el pedido de incautación, bajo responsabilidad.

Respecto de los efectos provenientes directos o indirectamente de la infracción penal, los objetos de la misma o los instrumentos o medios con que se hubiere ejecutado, se procederá además conforme a lo dispuesto en otras normas especiales.

\subsection{Otros supuestos de entrada legitima a un domicilio}

El Tribunal Constitucional peruano, en armonía con el artículo 2.9 constitucional, ha establecido una gama de situaciones que justifica la entrada al domicilio de una persona:

"(...)

- El ingreso al domicilio con el consentimiento del titular del derecho: este hecho constituye un supuesto de entrada legítima en términos constitucionales.

- La autorización judicial que habilita al agente público para ingresar al domicilio: la Constitución es clara cuando establece como requisito sine qua non para el ingreso a un 
domicilio - a efectos de realizar actividades investigatorias- la existencia de un mandato judicial, el mismo que se entiende tiene que estar debidamente motivado y su procedencia debe obedecer a un acto jurisdiccional regular.

- Frente a la existencia del delito flagrante: el agente público queda plenamente legitimado para ingresar al domicilio si es que su intervención se convierte en necesaria para impedir la consumación del ilícito penal, la fuga del delincuente o la desaparición de los instrumentos que facilitaron la concreción del acto delictivo.

- El peligro inminente de la perpetración de un delito: si es que se tiene el conocimiento fundado, la certeza clara y manifiesta de la comisión inminente de un delito, se configura otra excepción a la inviolabilidad de domicilio y en consecuencia el agente público puede operar libremente.

- Las razones de sanidad o grave riesgo: la Constitución ha dejado en manos del legislador la regulación de estas dos excepciones que legitiman la entrada a cualquier domicilio. Estos dos supuestos se fundan en el estado de necesidad o fuerza mayor". ${ }^{11}$

Fuera del caso de la autorización judicial que comentamos en el apartado anterior, tenemos otro supuesto, el cual gira en torno al consentimiento del titular del derecho para el ingreso al domicilio.

$\mathrm{Al}$ respecto, Palacios Criado precisa que el consentimiento del titular ha de ser: lógica.

"1. Libre, que no adolezca de vicio alguno por intimidación o presión psico-

2. Ha de prestarse por aquel que ostenta la titularidad del derecho, esto es, el morador.

3. Puede ser expreso o tácito, debiendo derivar en este último caso de actos inequívocos que así lo expresen" (Palacios, 1998, p. 237).

A ello, debemos de agregar que el consentimiento debe ser prestado por el morador y no por el dueño de la vivienda objeto de la diligencia de entrada y registro.

Si hay oposición entre los moradores, opinamos que debe prevalecer el criterio del que niega, por lo que no podrá practicarse la entrada y registro, por tratarse de un derecho eminentemente personal que afecta a la propia intimidad $y$, en consecuencia, también deberá solicitarse el mandamiento judicial.

En esta línea, escribe Arias Eibe, que "en el domicilio familiar hay que reconocer, frente a terceros, un derecho de exclusión a todos los que habitan en el mismo, y si bien en un primer momento se reconoció con exclusividad el derecho de exclusión al cabeza de familia, esta interpretación resulta hoy completamente obsoleta" (Arias, 2001, p. 03).

${ }^{11}$ Tribunal Constitucional del Perú. Bazán con Sala Penal de la Corte Superior de Justicia de Cañete (2008). 
Por otro lado, tenemos el supuesto de ingreso a un domicilio por haberse cometido un delito en forma flagrante. En ese sentido, se entiende por delito flagrante el que se está cometiendo o se acaba de cometer cuando el delincuente o delincuentes son sorprendidos. En esa inteligencia, Magro Servet precisa que "es requisito indispensable para la entrada en un domicilio sin la debida autorización que la situación de comisión del delito sea 'evidente', entendiéndose por tal lo que es cierto, claro, patente y sin la menor duda" (Magro, 2002, p. 1765).

$\mathrm{Al}$ respecto, el Tribunal Constitucional del Perú ha precisado lo siguiente: "Según lo ha establecido este Tribunal en reiterada jurisprudencia, la flagrancia en la comisión de un delito presenta dos requisitos insustituibles: a) la inmediatez temporal, es decir, que el delito se esté cometiendo o que se haya cometido instantes antes; b) la inmediatez personal, esto es, que el presunto delincuente se encuentre ahí, en ese momento en situación; y con relación al objeto o a los instrumentos del delito, que ello ofrezca una prueba evidente de su participación en el hecho delictivo (Cfr. STCs. Exp. No 2096-2004-HC/TC, caso Eleazar Camacho Fajardo; Exp. No 06646-2006-PHC/TC, caso Alberto Gonzalo Vega Sánchez; Exp. No6142-2006-PHC/TC, caso James Yovani Rodríguez Aguirre) ". ${ }^{12}$

Sin embargo, opinamos que a estos dos requisitos se debe de agregar uno más, el referente a la necesidad urgente, de tal modo que la Policía, por las circunstancias concurrentes en el caso concreto, se vea impelida a intervenir inmediatamente para evitar la progresión delictiva, la detención del delincuente y/o la obtención de pruebas que desaparecerían si se acudiera a solicitar la autorización judicial, necesidad que no existirá cuando la naturaleza de los hechos permita acudir al Juez para obtener el mandamiento correspondiente.

En resumen, la entrada y registro policial en un domicilio, sin previa autorización judicial y sin que medie consentimiento expreso de su titular, únicamente es admisible, desde el punto de vista constitucional, cuando dicha injerencia se produzca ante el conocimiento o percepción evidente de que en dicho domicilio se está cometiendo un delito, y siempre que la intervención policial resulte urgente para impedir su consumación, detener a la persona supuestamente responsable del mismo, proteger a la víctima o, por último, para evitar la desaparición de los efectos o instrumentos del delito.

Finalmente, existen dos supuestos más de ingreso a un domicilio. Así tenemos, por un lado, el peligro inminente de la perpetración de un delito: si es que se tiene el conocimiento fundado, la certeza clara y manifiesta de la comisión inminente

\footnotetext{
${ }^{12}$ Tribunal Constitucional del Perú. Hilario con Segunda Sala Especializada en lo Penal para procesos con reos libres de la Corte Superior de Justicia de Lima (2008).
} 
de un delito, se configura otra excepción a la inviolabilidad de domicilio y, en consecuencia, el agente público puede operar libremente; y por otro lado, las razones de sanidad o grave riesgo: las cuales se fundan en el estado de necesidad o fuerza mayor.

\section{El DERECHO A LA INVIOLABILIDAD DE LAS COMUNICACIONES Y LA INTERCEPTACIÓN DE LAS COMUNICACIONES}

"De los hechos conformados, materia del escrito de acusación fiscal, se tiene que el imputado Fujimori Fujimori controló la actividad política del país conjuntamente con su ex asesor Montesinos Torres y la activa participación de los comandantes generales de los institutos castrenses, ministros de Defensa e Interior y del Jefe del Servicio de Inteligencia Nacional.

Para coadyuvar a ello, se ideó y aplicó el denominado "Plan Emilio", el mismo que correspondía a acciones de interceptación o escuchas telefónicas de diversos ciudadanos adversos al régimen, ya sean periodistas, políticos, etcétera, y que se inició en los albores del régimen del citado acusado e incrementó luego del golpe de Estado del cinco de abril de mil novecientos noventa y dos, concluyendo tras la aparición del video Kouri/Montesinos, en el año dos mil.

Desde los cargos formulados por la Fiscalía resulta evidente que con el accionar del acusado Fujimori Fujimori se vulneró el secreto de las comunicaciones de diversas personas (...).

Se trata, en suma, de la evidente comisión consumada del delito de interferencia o escucha telefónica. El acusado Fujimori Fujimori dispuso la realización de esta actividad ilícita para tener el control de la actividad política del país, interviniendo las comunicaciones de personas adversas a su régimen, con la consiguiente vulneración del secreto de sus comunicaciones. En consecuencia, se acepta como tal la tipificación propuesta por la Fiscalía y la condición de autor de Alberto Fujimori Fujimori". ${ }^{13}$

La cita corresponde a un extracto de la sentencia emitida por la Sala Penal Especial de la Corte Suprema de Justicia del Perú, correspondiente al expediente No A.V. 33-2003, seguido contra Alberto Fujimori Fujimori como autor del delito de interferencia o escucha telefónicos y otros, en agravio de Javier Pérez de Cuéllar y otros.

En ese sentido, el delito de interceptación telefónica tipificado en el artículo 162 del Código Penal peruano presenta como bien jurídico protegido el derecho

${ }^{13}$ Sala Penal Especial de la Corte Suprema de Justicia del Perú. Fujimori con Estado peruano (2008). 
constitucional a la inviolabilidad de las comunicaciones, consagrado en el artículo $2^{\circ}$, inciso $10^{\circ}$ de la Constitución Política del Perú.

En esa inteligencia, el derecho de toda persona a la inviolabilidad de las comunicaciones personales viene reconocido en la Declaración Universal de los Derechos Humanos, así como en el Pacto Internacional de Derechos Civiles y Políticos.

Así, el artículo 12 de la Declaración Universal de los Derechos Humanos prohíbe las injerencias arbitrarias en la vida privada de los ciudadanos, haciendo referencia especialmente a la inviolabilidad de la correspondencia, a la vez que reconoce el derecho de toda persona a la protección de la ley contra tales injerencias o ataques, pronunciándose en similares términos el artículo 17 del Pacto Internacional de Derechos Civiles y Políticos.

Como se puede apreciar el derecho a la inviolabilidad de las comunicaciones encuentra su sustento en el derecho a la vida privada. Al respecto, el Tribunal Constitucional del Perú ha establecido lo siguiente:

"La vida privada de las personas es un límite válido del derecho a la información. Por ello, corresponde fijar algunos contenidos básicos del primero de los derechos mencionados con el fin de controlar jurisdiccionalmente el segundo.

Lo importante de dotar de un contenido constitucionalmente protegido a la vida privada en el presente caso se centra en que los recurrentes aseveran que la violación a su derecho a la tutela procesal efectiva, en el sentido de derecho a la defensa técnica, se basa en una consideración equivoca. Debe determinarse, por tanto, si dentro del derecho a la vida privada se puede dejar de abrigar un ámbito como el de la prostitución clandestina, máxime si el Poder Judicial ya tomó una decisión clara y concreta, al considerar que sí la protege. En primer lugar, es menester observar cómo ha sido reconocida en el ordenamiento juridico. En la Constitución, como derecho-regla base se ha prescrito en el artículo $2^{\circ}$, inciso 7, que toda persona tiene derecho a la intimidad personal y familiar. Además, existen otros dispositivos que siguen refiriéndose a este tema dentro del mismo artículo $2^{\circ}$ : el impedimento de que los servicios informáticos no suministren informaciones que afecten la intimidad personal y familiar (inciso 6); la inviolabilidad de domicilio (inciso 9); el secreto e inviolabilidad de comunicaciones y documentos privados (inciso 10); entre otros. Y pese a que el desarrollo constitucional de la materia es disperso, lo cierto es que la Declaración Universal de Derechos Humanos le da cierta coherencia y unidad. Así, en el artículo $12^{\circ}$ se sostiene que nadie será objeto de injerencias arbitrarias en su vida privada, su familia, su domicilio o su correspondencia, motivo por lo cual se expresa el derecho a la protección de la ley contra tales injerencias o ataques. Un planteamiento similar se puede encontrar en el artículo $17^{\circ}$ del Pacto Internacional de Derechos Civiles y Politicos y en el artículo $11^{\circ}$ de la Convención Americana sobre Derechos Humanos (sobre todo incisos 2 y 3). Menos amplio es el reconocimiento mostrado en el artículo $V$ de la Declaración Americana de los 
Derechos y Deberes del Hombre, que se restringe a señalar que toda persona tiene derecho a la protección de la ley contra los ataques abusivos a su vida privada y familiar." "4

Ello se debe al hecho que, el reducto de lo personal no encuentra su confín en la cárcel de la propia individualidad sino que ella sirve de plataforma para la integración del ser humano con el círculo de ciertos allegados (especialmente a través de los lazos familiares), con un ambiente físico (el domicilio) y con el ambiente inmaterial de sus manifestaciones espirituales (la correspondencia, las comunicaciones de todo tipo, los papeles privados).

Ahora bien, la garantía del artículo 2.10 de la Constitución peruana comprende desde luego a las comunicaciones postales, telegráficas y telefónicas, que son los tres medios más comunes en la actualidad, aunque no puede dudarse que se está ante una enumeración abierta, de modo que la norma extiende su ámbito a todas las formas existentes o que en el futuro puedan surgir cualquiera que sea el medio empleado -correo electrónico, internet, etc.

Igualmente, este derecho es protegido sin interesar el contenido de la comunicación, porque lo que está en juego es el derecho a la vida privada y familiar, ello incluye su domicilio, así como la correspondencia y demás comunicaciones.

En ese orden de ideas, el Tribunal Constitucional del Perú ha precisado lo siguiente:

"El concepto de 'secreto' e 'inviolabilidad' de las comunicaciones y documentos privados, desde esa perspectiva, comprende a la comunicación misma, sea cual fuere su contenido y pertenezca o no el objeto de la comunicación al ámbito de lo personal, lo intimo o lo reservado. De manera que se conculca el derecho tanto cuando se produce una interceptación de las comunicaciones, es decir, cuando se aprehende la comunicación dirigida a terceros, como cuando se accede al conocimiento de lo comunicado, sin encontrarse autorizado para ello". ${ }^{15}$

Sin embargo, el artículo 2.10 de la Constitución peruana no define el derecho a la inviolabilidad de las comunicaciones de modo absoluto, sino que admite la posibilidad de que por resolución judicial aparezca restringido, de modo que otras personas distintas de los interlocutores tengan acceso a sus comunicaciones; amplitud de expresión que permite incluir en el precepto las comunicaciones por medios como redes informáticas, radio, fax, teletipo, etc. (Majada, 1990, p. 531).

En ese sentido, el Tribunal Constitucional del Perú ha indicado lo siguiente: "En efecto, conforme lo establece el artículo $2^{\circ}$, inciso 10 ), de nuestra norma fundamental, toda persona tiene derecho a que sus comunicaciones y documentos privados sean adecuadamente protegidos, así como a que las mismas y los ins-

\footnotetext{
${ }^{14}$ Tribunal Constitucional del Perú. Medina con Cuarta Sala Especializada en lo Penal para procesos con reos libres de la Corte Superior de Justicia de Lima (2005).

${ }_{15}$ Tribunal Constitucional del Perú. Berrospi con Quinta Sala Civil de la Corte Superior de Justicia de Lima (2003).
} 
trumentos que las contienen, no puedan ser abiertas, incautadas, interceptadas o intervenidas sino mediante mandamiento motivado del juez y con las garantías previstas en la ley. Aunque, ciertamente, puede alegarse que la fuente o el soporte de determinadas comunicaciones y documentos le pertenecen a la empresa o entidad en la que un trabajador labora, ello no significa que la misma pueda arrogarse en forma exclusiva y excluyente la titularidad de tales comunicaciones y documentos, pues con ello evidentemente se estaría distorsionando el esquema de los atributos de la persona, como si éstos pudiesen de alguna forma verse enervados por mantenerse una relación de trabajo". ${ }^{16}$

Ante lo señalado, vamos a analizar las restricciones que puede sufrir el derecho a la inviolabilidad de las comunicaciones, en concreto, las que operan dentro del proceso penal; para ello, hemos estructurado los siguientes tópicos:

- Intervención de la correspondencia.

- Intervención de las comunicaciones telefónicas.

A continuación, desarrollaremos cada uno de estos puntos.

\subsection{Intervención de la correspondencia}

El derecho a la inviolabilidad de la correspondencia viene también recogido en el artículo 2.10 de la Constitución peruana, exigiéndose, en todo caso, autorización de la autoridad judicial para la detención o interceptación de la correspondencia postal, igual para el caso de la telegráfica y telefónica, como se verá en el siguiente apartado.

En efecto, la intervención de las comunicaciones postales, telegráficas y telefónicas exige una resolución judicial, que ha de revestir la forma de auto y ser "motivada". Al respecto, el Tribunal Constitucional del Perú ha precisado lo siguiente: "Este Colegiado ya ha tenido oportunidad de pronunciarse sobre la garantía de la inviolabilidad de las comunicaciones en el Expediente No 1058-2004-AA/TC señalando que conforme lo establece el artículo $2^{\circ}$, inciso 10 ), de nuestra norma fundamental, toda persona tiene derecho a que sus comunicaciones y documentos privados sean adecuadamente protegidos, así como a que las mismas y los instrumentos que las contienen, no puedan ser abiertas, incautadas, interceptadas o intervenidas sino mediante mandamiento motivado del juez y con las garantías previstas en la ley puntualizando que los documentos privados obtenidos con violación de los preceptos anteriormente señalados, no tienen efecto legal". ${ }^{17}$

\footnotetext{
${ }^{16}$ Tribunal Constitucional del Perú. García con Sexta Sala Civil de la Corte Superior de Justicia de Lima (2004).

${ }^{17}$ Tribunal Constitucional del Perú. Contreras con Quinta Sala Civil de la Corte Superior de Justicia de Lima (2009).
} 
Asimismo, el artículo 226 del Código Procesal Penal peruano, en su numeral 1 ), establece que las cartas, pliegos, valores, telegramas y otros objetos de correspondencia o envío postal, en las oficinas o empresas - públicas o privadas- postales o telegráficas, dirigidos al imputado o remitidos por él, aun bajo nombre supuesto, o de aquellos de los cuales por razón de especiales circunstancias, se presumiere emanan de él o de los que él pudiere ser el destinatario, pueden ser objeto, a instancia del Fiscal al Juez de la Investigación Preparatoria, de interceptación, incautación y ulterior apertura.

En ese sentido, la norma procesal faculta al Juez de la Investigación Preparatoria para ordenar la detención, apertura y examen de la correspondencia postal y telegráfica cuando existan indicios de obtener por estos medios el descubrimiento o la comprobación de algún hecho o circunstancia importante para la causa.

No obstante, por suponer la limitación de un derecho fundamental, la intervención de la correspondencia deberá acordarse sólo en supuestos en que realmente se considere imprescindible la adopción de esta medida; correspondiendo a la autoridad judicial la decisión en cada caso concreto para valorar si el hecho investigado tiene la suficiente entidad como para permitir utilizar este medio de búsqueda de pruebas.

$\mathrm{Al}$ respecto, el artículo 226 del texto adjetivo peruano, en su numeral 2), acota que la orden judicial se instará cuando su obtención sea indispensable para el debido esclarecimiento de los hechos investigados. Esta medida, estrictamente reservada y sin conocimiento del afectado, se prolongará por el tiempo estrictamente necesario, el que no será mayor que el período de la investigación. En el numeral 3) se señala que se podrá disponer la obtención de copias o respaldos de la correspondencia electrónica dirigida al imputado o emanada de él. Asimismo, en el numeral 4) se apunta que el Juez de la Investigación Preparatoria resolverá, mediante trámite reservado e inmediatamente, teniendo a la vista los recaudos que justifiquen el requerimiento fiscal. La denegación de la medida podrá ser apelada por el Fiscal, e igualmente se tramitará reservada por el Superior Tribunal, sin trámite alguno e inmediatamente.

Ahora bien, el criterio de la proporcionalidad entre el hecho investigado y la restricción de los derechos fundamentales que la medida de interceptación supone es la clave para adoptar la decisión más razonable en cada caso concreto. Este criterio de la proporcionalidad no sólo ha de tener en cuenta la presunta gravedad jurídica de los hechos, sino otras consideraciones, como son la gravedad social de los hechos investigados y las dificultades existentes para investigar los hechos delictivos.

En esta línea, escribe Paz Rubio que "el derecho fundamental al secreto de las comunicaciones postales obliga a la mayor escrupulosidad legal a la hora de 
intervenir cualquier clase de correspondencia, por lo que es necesario en todo caso, respetando los principios de legalidad y de proporcionalidad, examinar la importancia, la naturaleza y la trascendencia de la medida de registro en relación con la gravedad de la presunta infracción, para, en su consecuencia, dictar, si procediere, la oportuna autorización judicial, específica y razonada" (Paz, 1999, p. 306).

Además, como dice Moreno Catena, en la obra colectiva Derecho procesal penal, dirigido por Gimeno Sendra, "la medida sólo puede acordarse en el marco de una investigación penal en curso. Ello supone que la autoridad judicial únicamente puede ordenarla o utilizarla" (Gimeno, 1997, p. 455).

En esa inteligencia, la intervención de la correspondencia exige resolución judicial fundada en la que se sopesen, conforme al principio de proporcionalidad, la gravedad de la posible infracción criminal y la importancia de esta injerencia en la intimidad de las personas.

Ahora bien, y de acuerdo con el numeral 1) del artículo 227 del Código Procesal Penal del Perú, recabada la autorización, el Fiscal -por sí o encargando su ejecución a un funcionario de la Fiscalía o un efectivo Policial- realizará inmediatamente la diligencia de interceptación e incautación. Acto seguido examinará externamente la correspondencia o los envíos retenidos, sin abrirlos o tomar conocimiento de su contenido, y retendrá aquellos que tuvieren relación con el hecho objeto de la investigación. De lo actuado se levantará un acta.

En esa inteligencia, el primer paso es la detención de la correspondencia, la cual consiste en la aprehensión física del soporte que se remite, bien mediante transporte del objeto -carta, paquete-, bien mediante la transmisión por vía telegráfica de un mensaje. Con ello se impide que el envío pueda llegar a conocimiento de su destinatario, porque si éste lo tuviera en su poder habría de ordenarse la diligencia de registro de libros y papeles.

El segundo paso es la apertura, la cual denota cualquier procedimiento que permita ver directamente o tocar o tomar muestras de algo que está cerrado, es decir, averiguar el contenido de un paquete mediante manipulación externa. En ese sentido, y de acuerdo con el numeral 2) del artículo 227 del texto adjetivo peruano, la apertura se efectuará en el despacho del Fiscal. El Fiscal leerá la correspondencia o revisará el contenido del envío postal retenido. Si tienen relación con la investigación dispondrá su incautación, dando cuenta al Juez de la Investigación Preparatoria. Por el contrario, si no tuvieren relación con el hecho investigado serán devueltos a su destinatario -directamente o por intermedio de la empresa de comunicaciones-. La entrega podrá entenderse también con algún miembro de la familia del destinatario, a algún miembro de su familia o a su mandatario o representante legal. Cuando solamente una parte tenga relación con el caso, 
a criterio del Fiscal, se dejará copia certificada de aquella parte y se ordenará la entrega a su destinatario o viceversa.

No obstante, del dispositivo normativo se advierte que la apertura de la correspondencia no se realiza en presencia del afectado; por lo que, una vez terminada la diligencia, el mismo podrá solicitar el reexamen judicial de lo actuado, de conformidad con el artículo 228 del Código Procesal Penal peruano, el cual precisa que cumplida la diligencia y realizadas las investigaciones inmediatas en relación al resultado de aquélla, se pondrá en conocimiento del afectado todo lo actuado, quien puede instar el reexamen judicial, dentro del plazo de tres días de notificado. La audiencia se realizará con asistencia del afectado, de su defensor y de las demás partes. El Juez decidirá si la diligencia se realizó correctamente y si la interceptación e incautación han comprendido comunicaciones relacionadas con la investigación.

Finalmente, y de conformidad con el artículo 229 del texto adjetivo peruano, si la persona en cuyo poder se encuentra la correspondencia, al ser requerida se niega a entregarla, será informada que incurre en responsabilidad penal. Si persiste en su negativa, se redactará acta de ésta y seguidamente se le iniciará la investigación pertinente. Si dicha persona alegare como fundamento de su negativa, secreto de Estado o inmunidad diplomática, se procederá conforme al numeral 3) del artículo 224 del Código Procesal Penal del Perú en el primer caso y se solicitará informe al Ministerio de Relaciones Exteriores en el segundo caso.

\subsection{Intervención de las comunicaciones telefónicas}

El tema de la intervención de las comunicaciones telefónicas es muy sensible y revela la fortaleza o no del Estado de Derecho.

En ese sentido, tenemos jurisprudencia que, admitiendo la intervención indebida de las comunicaciones telefónicas, ha declarado improcedente una demanda de amparo, hasta otra que reprende severamente al Ministerio Público por haber usado este instrumento violentando los derechos humanos de los afectados.

En el primer caso, citamos una sentencia del Tribunal Constitucional peruano que señala lo siguiente: “...que en el caso de autos, no se produjo tal convicción en razón que de las cintas y transcripciones ofrecidas con la demanda se evidenciaban la escucha de las comunicaciones en los que participaban los demandantes, no suministraban sin embargo, indicios objetivos que de éstas hubiesen sido interceptadas por la entidad demandada, al extremo de que en su propio petitorio de la demanda, a fuerza de no tenerse". ${ }^{18}$

\footnotetext{
${ }^{18}$ Tribunal Constitucional del Perú. Townsend con Sala Corporativa Transitoria Especializada en Derecho Público de la Corte Superior de Justicia de Lima (1998). Se debe resaltar que los demandantes, entonces Congresistas,
} 
El segundo caso gira en torno a la siguiente sentencia emitida por la Corte Interamericana de Derechos Humanos:

"La Corte considera que la conversación telefónica entre el señor Adel Zayed y el señor Tristán Donoso era de carácter privado y ninguna de las dos personas consintió que fuera conocida por terceros. Más aún, dicha conversación, al ser realizada entre la presunta victima y uno de sus clientes debería, incluso, contar con un mayor grado de protección por el secreto profesional.

- La divulgación de la conversación telefónica por parte de un funcionario público implicó una injerencia en la vida privada del señor Tristán Donoso. La Corte debe examinar si dicha injerencia resulta arbitraria o abusiva en los términos del artículo 11.2 de la Convención o si resulta compatible con dicho tratado. Como ya se indicó (supra párr. 56), para ser compatible con la Convención Americana una injerencia debe cumplir con los siguientes requisitos: estar prevista en ley, perseguir un fin legitimo, y ser idónea, necesaria y proporcional. En consecuencia, la falta de cumplimiento de alguno de dichos requisitos implica que la medida es contraria a la Convención. - Finalmente, este Tribunal aprecia que las expresiones del ex Procurador al realizar la divulgación (supra párrs. 43 y 44 ) pueden considerarse como una afectación a la honra y reputación incompatible con la Convención en perjuicio del señor Tristán Donoso, toda vez que la calificación de las expresiones contenidas en el casete como un plan de difamación', o como 'una confabulación en contra de la cabeza del Ministerio Público' por parte de la máxima autoridad del órgano encargado de perseguir los delitos, ante dos auditorios relevantes para la vida de la presunta víctima, implicaban la participación de ésta en una actividad ilícita con el consecuente menoscabo en su honra y reputación. La opinión que las autoridades de la Iglesia Católica y del Colegio Nacional de Abogados tuvieran sobre la valía y actuación de la presunta victima necesariamente incidia en su honra y reputación (supra párr. 34).

- La Corte considera que la divulgación de la conversación privada ante autoridades de la Iglesia Católica y algunos directivos del Colegio Nacional de Abogados, y las manifestaciones utilizadas por el ex Procurador en dichas ocasiones, violaron los derechos a la vida privada y a la honra y reputación del señor Tristán Donoso, reconocidos en los artículos 11.1 y 11.2 de la Convención Americana, en relación con la obligación de respeto consagrada en el artículo 1.1 del mismo tratado". ${ }^{19}$

$\mathrm{Al}$ respecto, nadie discute la importancia de la intervención de las comunicaciones telefónicas para la investigación de un delito, pero la propia Constitución ha establecido el mecanismo que esta figura debe recurrir.

imputaban la intervención telefónica al Servicio de Inteligencia Nacional, controlada por el entonces asesor Vladimiro Montesinos, pero, a pesar de las denuncias periodísticas que sustentaban la presente demanda de amparo, los entonces miembros del Tribunal Constitucional lo declararon improcedente.

${ }^{19}$ Corte Interamericana de Derechos Humanos. Tristán con Panamá (2009). 
Sin embargo, es menester que definamos lo que se entiende como intervención de las comunicaciones telefónicas.

Para Rodríguez Ramos, la modalidad de la intervención puede consistir en la "escucha directa de las conversaciones que se hagan desde o a un teléfono determinado -también puede extenderse su ámbito al telefax y al módem-, en su grabación y/o en la transcripción de lo grabado, según se acuerde en el correspondiente auto" (Rodríguez, 2003, p. 240).

López Fragoso define las intervenciones telefónicas como "aquellas medidas instrumentales restrictivas del derecho fundamental al secreto de las comunicaciones privadas, ordenadas y ejecutadas en la fase instructora de un proceso penal bajo la autoridad del órgano jurisdiccional competente frente a un imputado -u otros sujetos de los que éste se sirva para comunicarse- con el fin de, a través de la captación del contenido y de lo comunicado o de otros aspectos del proceso de comunicación, investigar determinados delitos, averiguar al delincuente $\mathrm{y}$, en su caso, aportar al juicio oral determinados elementos probatorios" (López-Fragoso, 1991, p. 12).

Asimismo, el artículo 230, numeral 1) del Código Procesal Penal peruano, precisa que el Fiscal, cuando existan suficientes elementos de convicción para considerar la comisión de un delito sancionado con pena superior a los cuatro años de privación de libertad y la intervención sea absolutamente necesaria para proseguir las investigaciones, podrá solicitar al Juez de la Investigación Preparatoria la intervención y grabación de comunicaciones telefónicas, radiales o de otras formas de comunicación. Rige lo dispuesto en el numeral 4) del artículo 226 del citado cuerpo de leyes.

$\mathrm{Al}$ respecto, se resalta la figura del teléfono. En ese sentido, Paz Rubio entiende por teléfono "cualquier medio de comunicación sea alámbrico o inalámbrico, que sirva para transmitir por cable o por el espacio radioeléctrico -telefonía digital y por satélite incluida-, el sonido, identificable en mensajes" (Paz, 1999, p. 209). Sin embargo, el objeto material de esta medida son las comunicaciones efectuadas a través de teléfonos móviles o convencionales, así como los sonidos o señales emitidos en la transmisión de los faxes, teletipos, videoconferencias, correspondencia informática o cualesquiera otro sonido que se sirva de la red telefónica -por cable o por el espacio-solución que viene abonada legislativamente, puesto que ninguna de las normas legales -sustantivas o procesales- distinguen el cauce tecnológico por el que se tengan que establecer las comunicaciones telefónicas.

En esa inteligencia, y teniendo en cuenta las posibilidades que hoy día ofrece la comunicación vía telefónica, Marchal Escalona describe el triple ámbito que puede abarcar la medida de intervención: 
“a) Números marcados e identidad de los interlocutores. Si en la intervención u observación apareciere un número secreto -solicitada la exclusión de listados por su titular-, deberá recabarse de la autoridad judicial que por la Compañia operadora afectada se faciliten los datos de aquellos que surjan en el desarrollo de la misma, lo cual puede hacerse, bien en la petición originaria de interceptación, bien en otra posterior a la vista de los resultados. Todo ello con independencia de la modalidad del servicio telefónico y compañia utilizada -fijo o móvil, analógico o digital-.

b) Comunicación telefónica verbal. Conocimiento y registro de todas las comunicaciones recibidas y transmitidas desde un abonado concreto.

c) Comunicación de datos vía telefónica. Debido al avance de la tecnología por vía telefónica y al margen de la conversación, hoy pueden transmitirse mensajes de fax y comunicación módem, transmisión de datos informatizados, bien de un usuario a otro, bien a través de una red" (Marchal, 2003, p. 217).

Por otro lado, la intervención telefónica presenta las siguientes notas características:

1. Exclusividad jurisdiccional. Únicamente por la autoridad judicial se pueden establecer restricciones y derogaciones al derecho al secreto de las comunicaciones telefónicas.

2. Finalidad exclusivamente probatoria. Es decir, la intervención ha de ir encaminada a establecer la existencia del delito y el descubrimiento de las personas responsables del mismo, ya que una medida de búsqueda de pruebas que limite un derecho fundamental no puede estar dirigido exclusivamente a obtener meros indicios o sospechas de criminalidad, sino a preconstituir la prueba de los hechos que integran el objeto del proceso penal.

En consecuencia, no son posibles las intervenciones preventivas o exploratorias desligadas de la realización de un hecho delictivo y tendentes sólo a determinar la realización de hipotéticas conductas criminales, pues tal restricción del derecho, desproporcionada e indiscriminada, sería contraria al sistema de garantías constitucionales, que también se extienden a la fase de investigación penal (Paz, 1999, p. 222).

3. Especialidad de la materia a investigar. Es decir, no cabe decretar la intervención telefónica para propiciar el descubrimiento genérico de posibles infracciones penales, lo que supondría conceder autorizaciones en blanco, antes al contrario se precisa indicar el tipo delictivo que se está investigando, que algunas veces puede incluso modificarse posteriormente, no por novación de dicho tipo sino por adición o suma de otras peculiaridades penales.

En ese sentido, quedan prohibidas las escuchas predelictuales o de prospección, desligadas de la realización de un hecho delictivo concreto; es decir, aquellas 
encaminadas a ver qué se descubre, por puro azar, para sondear, sin saber qué delito se va a descubrir.

Esta característica es recogida en el artículo 230, numeral 1) del Código Procesal Penal peruano, cuando precisa que el Fiscal, cuando existan suficientes elementos de convicción para considerar la comisión de un delito sancionado con pena superior a los cuatro años de privación de libertad y la intervención sea absolutamente necesaria para proseguir las investigaciones, podrá solicitar al Juez de la Investigación Preparatoria la intervención y grabación de comunicaciones telefónicas, radiales o de otras formas de comunicación.

4. Existencia de indicios delictivos. La adopción de la medida exige previa existencia de indicios delictivos, no equivalentes a las meras sospechas o conjeturas, en tanto que es la probabilidad de la presunta infracción la que marcará la pauta a seguir, que en eso precisamente consiste la proporcionalidad, todo lo cual descarta desde luego las escuchas predelictuales o de prospección si van desligadas de la realización de hechos delictivos concretos.

En esa inteligencia, la relación entre la persona investigada y el delito se manifiesta en las sospechas, las cuales no son tan sólo circunstancias meramente anímicas, sino que precisan, para que puedan entenderse fundadas, hallarse apoyadas en datos objetivos, que han de serlo en un doble sentido; en primer lugar, en el de ser accesibles a terceros, sin lo que no serían susceptibles de control y, en segundo lugar, en el que han de proporcionar una base real de la que pueda inferirse que se ha cometido un delito, sin que puedan consistir en valoraciones acerca de la persona.

Igualmente, esta característica está presente en el citado artículo 230, numeral 1) del texto adjetivo peruano.

5. Excepcionalidad de la medida. Esto es, sólo habrá de adoptarse cuando no exista otro medio de búsqueda de prueba o diligencia de investigación que sea de menor incidencia y causación de daño sobre los derechos y libertades fundamentales del individuo que los que inciden sobre la intimidad personal y el secreto de las comunicaciones.

En opinión de Majada, "la intervención debe reducirse a asuntos de excepcional gravedad y siempre que exista la convicción del Juez de que es el único medio o el esencial para la averiguación de los hechos, añadiendo que las intervenciones telefónicas han de estar muy fundamentadas y para decidirlas o no han de valorarse especialmente criterios de urgencia, teniendo siempre muy presente que llevan en sí una intromisión en la intimidad de las personas, con pleno acceso a conversaciones particulares sobre relaciones profesionales, laborales, políticas y de toda índole” (Majada, 1990, p. 532). 
En el mismo sentido, Moreno Catena señala que "la diligencia ha de resultar excepcional, de modo que la motivación del auto habrá de expresar las razones que llevan al juzgador a considerar necesaria la intervención para obtener datos relevantes en la investigación penal, siempre con una rigurosa ponderación de los intereses en conflicto y teniendo en cuenta que la investigación penal no es, desde luego, un valor supremo, y habiendo otras alternativas menos gravosas para el derecho fundamental o medios de investigación que no le afecten se habrá de optar por ellos" (Gimeno, 1997, p. 455).

Asimismo, para Rodríguez Ramos, "es requisito esencial para acordar esta medida interventora de una comunicación telefónica la de calibrar su necesidad, tanto desde la perspectiva de la probable utilidad -idoneidad-cuanto de su cualidad de insustituible, pues si no es probable que se obtengan datos esenciales para la investigación o puedan éstos lograrse por otros medios menos gravosos, el principio de proporcionalidad vetaría su adopción” (Rodríguez, 2003, p. 350).

6. Proporcionalidad. El Juez ha de operar con un criterio de proporcionalidad, en el sentido de que únicamente cuando la medida se justifique en razón de la gravedad del hecho y de lo que con ello se puede descubrir o comprobar se podrá decretar la intervención.

7. Se puede intervenir teléfonos que utilicen las personas presuntamente implicadas, así como de terceras personas. El numeral 2) del artículo 230 del Código Procesal Penal peruano, señala que la orden judicial puede dirigirse contra el investigado o contra personas de las que cabe estimar fundadamente, en mérito a datos objetivos determinados que reciben o tramitan por cuenta del investigado determinadas comunicaciones, o que el investigado utiliza su comunicación.

8. Resolución judicial motivada. Según Gimeno Sendra, "la motivación judicial se refiere como el oportuno juicio de la indispensabilidad de la intervención telefónica para preconstituir la prueba necesaria para la actuación del ius puniendi del Estado, de tal suerte que quede suficientemente acreditado que, sin dicha intervención, en ningún caso podría probarse el hecho mediante la utilización de otros medios menos lesivos para el libre ejercicio de éste u otro derecho fundamental" (Gimeno, 1996, p. 1620).

En ese sentido, el numeral 3) del artículo 230 del Código Procesal Penal del Perú, indica que el requerimiento del Fiscal y, en su caso, la resolución judicial que la acuerde, deberá indicar el nombre y dirección del afectado por la medida, así como, de ser posible, la identidad del teléfono u otro medio de comunicación o telecomunicación a intervenir y grabar o registrar. También indicará la forma de la interceptación, su alcance y su duración, al igual que la autoridad o funcionario, policial o de la propia Fiscalía, que se encargará de la diligencia de interceptación y grabación o registro. 
Finalmente, en cuanto al procedimiento para ejecutar la intervención telefónica, y teniéndose en cuenta lo dispuesto en los artículos 230 y 231 del Código Procesal Penal peruano, se deberá observar los siguientes pasos:

a) Las empresas telefónicas y de telecomunicaciones deberán posibilitar la diligencia de intervención y grabación o registro, bajo apercibimiento de ser denunciados por delito de desobediencia a la autoridad. Los encargados de realizar la diligencia y los servidores de las indicadas empresas deberán guardar secreto acerca de la misma, salvo que se les citare como testigos al procedimiento.

b) Si los elementos de convicción tenidos en consideración para ordenar la medida desaparecen o hubiere transcurrido el plazo de duración fijado para la misma, ella deberá ser interrumpida inmediatamente.

c) La interceptación no puede durar más de treinta días. Excepcionalmente podrá prorrogarse por plazos sucesivos, previo requerimiento del Fiscal y decisión motivada del Juez de la Investigación Preparatoria.

d) La intervención de comunicaciones telefónicas, radiales o de otras formas de comunicación será registrada mediante su grabación magnetofónica u otros medios técnicos análogos que aseguren la fidelidad del registro. La grabación será entregada al Fiscal, quien dispondrá su conservación con todas las medidas de seguridad correspondientes y cuidará que la misma no sea conocida por terceras personas.

e) El Fiscal dispondrá la transcripción escrita de la grabación, levantándose el acta correspondiente, sin perjuicio de conservar los originales de la grabación. Las comunicaciones que fueren irrelevantes para el procedimiento serán entregadas, en su oportunidad, a las personas afectadas con la medida, y se destruirá toda la transcripción o copias de ellas por el Ministerio Público. No rige respecto de aquellas grabaciones que contuvieren informaciones relevantes para otros procedimientos en tanto pudieren constituir un hecho punible.

f) Una vez ejecutada la medida de intervención y realizadas las investigaciones inmediatas en relación al resultado de aquélla, se pondrá en conocimiento del afectado todo lo actuado, quien puede instar el reexamen judicial, dentro del plazo de tres días de notificado. La notificación al afectado sólo será posible si el objeto de la investigación lo permitiere y en tanto no pusiere en peligro la vida o la integridad corporal de terceras personas. El secreto de las mismas requerirá resolución judicial motivada y estará sujeta a un plazo que el Juez fijará.

g) La audiencia judicial de reexamen de la intervención se realizará en el más breve plazo. Estará dirigida a verificar sus resultados y que el afectado haga valer sus derechos y, en su caso, impugnar las decisiones dictadas en ese acto. 


\section{El DERECHO A LA LibERTAD PERSONAL Y LA DETENCIÓN POR DELITO FLAGRANTE}

\subsection{La libertad personal}

Para el Tribunal Constitucional del Perú: "El inciso 24 del artículo 2o de la Constitución reconoce el derecho fundamental a la libertad personal. Se trata de un derecho subjetivo en virtud del cual ninguna persona puede sufrir una limitación o restricción a su libertad física o ambulatoria, ya sea mediante detenciones, internamientos o condenas arbitrarias. La plena vigencia del derecho fundamental a la libertad personal es un elemento vital para el funcionamiento del Estado social y democrático de derecho, pues no sólo es una manifestación concreta del valor libertad implícitamente reconocido en la Constitución, sino que es presupuesto necesario para el ejercicio de otros derechos fundamentales". ${ }^{20}$

Al respecto, la libertad no resulta ser una facultad o una propiedad de la cual el hombre puede disponer o no. Es decir, el hombre no tiene o deja de tener libertad, sino que el hombre es libertad (Sartre, 1947, p. 33). La existencia implica libertad, por lo que esta es el dato ontológico primario del hombre.

Sin embargo, la libertad ha sido impuesta al hombre como su responsabilidad (Jaspers, 1933, p. 187). Por ser libre, el hombre es responsable de su existencia y de la de los demás con quienes coexiste. Por otro lado, el hombre como ser libre-que se proyecta, que realiza una estimativa-, adquiere el rango de persona humana; así, la persona espiritual es libre en su más hondo centro (Fernández, 1994, p. 73).

Esta última indicación nos brinda los siguientes términos: responsabilidad, persona humana, e incluso (deduciblemente) la coexistencia, los cuales no se agotan en el ámbito filosófico o metafísico de la libertad, sino que se desenvuelven en el mundo jurídico. Por lo tanto, la libertad puede, también, ser estudiada desde el punto de vista del Derecho.

En ese sentido, el Derecho incide en la libertad, al menos, desde dos perspectivas: a) el conjunto de derechos que toda persona tiene debido a su naturaleza, esto es, por ser persona (así tenemos, por ejemplo, los campos de los derechos humanos, Derecho constitucional, Derecho civil, Derecho penal, entre otros), y b) como fundamento iusfilosófico del juicio de reproche o de responsabilidad (es decir, la presencia o no del libre albedrío para fundar el juicio de culpabilidad, el cual se desarrolla en el Derecho penal exclusivamente).

Por otro lado, el artículo $2^{\circ}$, inciso 24) de la Constitución Política del Perú dispone que: "toda persona tiene derecho a la libertad y seguridad personales".

\footnotetext{
${ }^{20}$ Tribunal Constitucional del Perú. 31 congresistas con Congreso de la República del Perú (2005).
} 
Y a continuación, en ocho apartados, desarrolla las situaciones jurídicas que las mencionadas libertad y seguridad significan. Especial mención merece el apartado "b" al señalar que: "(n)o se permite formar alguna de restricción de la libertad personal, salvo los casos previstos por la ley".

En este mismo sentido se puede leer en el artículo $9^{\circ}$, inciso 1) del Pacto Internacional de Derechos Civiles y Políticos, el cual precisa:

"(t)odo individuo tiene derecho a la libertad y a la seguridad personales. Nadie podrá ser privado de su libertad, salvo por las causas fijadas por la ley y con arreglo al procedimiento establecido en ésta".

De igual modo en el artículo $7^{\circ}$ del Pacto de San José de Costa Rica, cuando dispone que:

"1. Toda persona tiene derecho a la libertad y a la seguridad personal. 2. Nadie puede ser privado de su libertad fisica, salvo por las causas y en las condiciones fijadas de antemano por las Constituciones Politicas de los Estados Partes o por las leyes dictadas conforme a ella. 3. Nadie puede ser sometido a detención o encarcelamiento arbitrarios".

Para Eguiguren, la libertad personal "comprende una libertad física o ambulatoria, que reconoce a toda persona la facultad de desplazarse libremente, sin otras limitaciones que las impuestas por el medio en que se pretende actuar y las establecidas por las normas constitucionales para preservar otros derechos o valores igualmente relevantes" (Eguiguren, 2002, pp. 27-28).

En ese orden de ideas, la libertad ambulatoria o personal es un derecho subjetivo y, al mismo tiempo, uno de los valores fundamentales de nuestro Estado Constitucional de Derecho, por cuanto fundamenta diversos derechos constitucionales a la vez que justifica la propia organización constitucional. ${ }^{21}$

Como derecho subjetivo, la libertad ambulatoria garantiza que no se afecte indebidamente la libertad física de las personas, esto es, su libertad locomotora, ya sea mediante detenciones, internamientos o condenas arbitrarias. Los alcances de la garantía dispensada a esta libertad comprenden frente a cualquier supuesto de privación de la libertad locomotora, independientemente de su origen, la autoridad o persona que le haya efectuado. Garantiza, pues, ante cualquier restricción arbitraria de la libertad personal, según señala el artículo 9o de la Declaración Universal de Derechos humanos y el artículo 7.3 de la convención Americana de Derechos Humanos (Castillo, 2004, p. 318).

El derecho a la libertad ambulatoria es un derecho constitucional, dado que es una expresión de la dignidad humana y de la libertad, dispuesta normativamente,

${ }^{21}$ Tribunal Constitucional del Perú. Silva con Segunda Sala Penal Corporativa para procesos ordinarios con reos libres de la Corte Superior de Justicia de Lima (2002). 
que supongan un conjunto de facultades para su titular, y que vinculen positiva y negativamente al poder político al punto de legitimar su actuación (Castillo, 2003, p. 37).

En esa inteligencia, el Tribunal Constitucional del Perú ha precisado lo siguiente: "El derecho fundamental a la libertad personal tiene un doble carácter. Es un derecho subjetivo, pero también una institución objetiva valorativa. Como derecho fundamental (artículo 20, inciso 24, de la Constitución) garantiza que no se afecte indebidamente la libertad física de las personas; esto es, su libertad locomotora, ya sea mediante detenciones, internamientos o condenas arbitrarias. Como derecho objetivo, es uno de los valores fundamentales de nuestro Estado social y democrático de Derecho, por cuanto informa nuestro sistema democrático y el ejercicio de los demás derechos fundamentales; a la vez que justifica la propia organización constitucional.

Los alcances de la garantía dispensada a esta libertad operan frente a cualquier supuesto de privación o restricción de la libertad locomotora, independientemente de su origen, la autoridad o persona que la haya efectuado. Garantiza, pues, ante cualquier privación o restricción arbitraria de la libertad personal, según señala el artículo $9^{\circ}$ de la Declaración Universal de Derechos Humanos y el artículo 7.3 de la Convención Americana de Derechos Humanos. En sede judicial, el derecho a la libertad física garantiza que ésta no sea restringida en forma arbitraria, lo cual alcanza no sólo a las denominadas 'detenciones judiciales preventivas', a una condena emanada de una sentencia expedida con violación del debido proceso, sino también a la ilegal y arbitraria imposición de medidas de seguridad que se derivan de una resolución judicial". ${ }^{22}$

Por otro lado, conviene precisar que, en doctrina, se sostiene que la libertad individual tiene una dimensión más amplia que la libertad ambulatoria. Así, Alzaga, en cita tomada por Castañeda, concibe la libertad ambulatoria como un "principio que tiene su desarrollo constitucional en otros preceptos de la misma, con lo cual se amplía el contenido hasta lo que la doctrina francesa denomina libertad física, comprensiva de la libertad individual en un sentido estricto, la circulación y el derecho a la intimidad" (Castañeda, 2005, p. 93).

Eguiguren indica que "en su aspecto de libertad física, garantiza a su titular el no verse arbitraria o irrazonablemente privado de ésta, ni ser detenido o sometido a restricciones de la libertad en supuestos distintos a los previstos por la norma constitucional, la ley o los pactos internacionales sobre derechos humanos" (Eguiguren, 2002, pp. 27-28).

\footnotetext{
${ }^{22}$ Tribunal Constitucional del Perú. Yupanqui con Segunda Sala Mixta Descentralizada de La Merced (2006).
} 
Más allá de la distinción entre los conceptos de libertad individual o libertad personal o ambulatoria, el contenido de este derecho está dado en la libertad física, de locomoción o ambulatoria, aspecto de la libertad que suele identificarse con la expresión libertad personal. Espinosa-Saldaña acota que "el término en rigor debería ser la libertad personal, dado que, lo que se está hablando es el pleno ejercicio de la dimensión más bien física de aquel derecho y valor que se conoce con el nombre de libertad. Como es de conocimiento general, esta faceta de la libertad (entendida al mismo tiempo como autodeterminación y no interferencia) es doctrinariamente conocida con el nombre de la libertad personal” (Espinosa-Saldaña, 2003, p. 146).

En otras palabras, está referida al reconocimiento que hace el ordenamiento jurídico de la capacidad de autodeterminación libre y voluntaria del ejercicio de las facultades ambulatorias o de locomoción de las personas.

En esa inteligencia, el Tribunal Constitucional peruano ha apuntado que: "Al respecto, cabe señalar que la adopción del mandato de detención y su mantenimiento importan la afectación del derecho a la libertad personal. Este es un derecho subjetivo reconocido en el artículo $2^{\circ}$, inciso 24), de la Constitución Política del Perú y, al mismo tiempo, es uno de los valores fundamentales de nuestro Estado constitucional de derecho, por cuanto fundamenta diversos derechos fundamentales.

En cuanto derecho subjetivo, el derecho a la libertad personal garantiza que no se afecte indebidamente la libertad física de las personas, esto es, su libertad locomotora, ya sea mediante detenciones, internamientos o condenas arbitrarias o ilegales. Los alcances de la garantía dispensada a esta libertad se extienden a cualquier supuesto de privación de la libertad locomotora, independientemente de su origen y de la autoridad o persona que la haya ordenado. Garantiza, por tanto, la libertad personal ante cualquier restricción arbitraria (artículo $9^{\circ}$ de la Declaración Universal de Derechos Humanos y artículo 7.3 de la Convención Americana de Derechos Humanos)" ${ }^{23}$

\subsection{La detención}

\subsubsection{El derecho a la libertad personal y sus restricciones}

En reiteradas jurisprudencias, el Tribunal Constitucional del Perú ha precisado que el derecho a la libertad personal no es absoluto, sino que su ejercicio puede sufrir restricciones o limitaciones. Al respecto, citamos los siguientes pronuncia-

\footnotetext{
${ }^{23}$ Tribunal Constitucional del Perú. Chávez con Segunda Sala Penal de la Corte Superior de Justicia de Ica (2005).
} 
mientos del supremo intérprete de la Constitución: "Sin embargo, el derecho fundamental a la libertad personal no es un derecho absoluto sino relativo, según este Tribunal ha sostenido en reiterada jurisprudencia (por ejemplo, Exp. No 2516-2005-HC/TC). Por lo que, por previsión constitucional, está sometido a ciertos límites, como por ejemplo los previstos en el artículo $2^{\circ}$, inciso 24, literal f, de la Constitución. En estos casos, la libertad personal puede verse legítimamente restringida. Por ello, no toda privación o restricción del derecho a la libertad es inconstitucional. Ahora bien, es evidente que la aplicación de la medida de internación constituye una restricción del derecho fundamental a la libertad personal. Sin embargo, para que el ingreso de una persona, por orden judicial, a un centro de internamiento sea constitucionalmente legítimo, es necesario que ella se realice en los casos y supuestos previstos en nuestro ordenamiento jurídico". ${ }^{24}$

Ahora bien, la gama de restricciones al derecho a la libertad personal giran en torno a lo siguiente: "El derecho a la libertad personal, como todo derecho fundamental, no es absoluto; el artículo $2^{\circ}$, inciso 24 , ordinales "a" y "b", establece que está sujeto a regulación, de modo que puede ser restringido o limitado mediante la ley. A tal efecto, los límites que puede imponérsele son intrínsecos y extrínsecos; los primeros se deducen de la naturaleza y configuración del derecho en cuestión, mientras que los segundos provienen del ordenamiento jurídico, cuyo fundamento se encuentra en la necesidad de proteger o preservar otros bienes, valores o derechos constitucionales". ${ }^{25}$

En esa inteligencia, el Tribunal Constitucional peruano ha precisado que la restricción a la libertad personal a mérito de la imposición de una medida cautelar es constitucionalmente válido: "En general, en el caso de las disposiciones que restringen la libertad del imputado como medida cautelar, existen dos intereses que deben ser cautelados por el Estado; esto es, a) la garantía a un proceso penal eficiente que permita la sujeción al proceso penal de la persona a quien se imputa un delito, y b) la garantía a la protección de los derechos fundamentales del imputado. Estos intereses, aparentemente contrapuestos, deben lograr un verdadero equilibrio a fin de no menoscabar la protección de uno frente al otro, siendo la regla general la libertad.

\footnotetext{
${ }^{24}$ Tribunal Constitucional del Perú. Yupanqui con Segunda Sala Mixta Descentralizada de La Merced (2006). Idéntico en Mallma con Segunda Sala Especializada en lo Penal para procesos con reos en cárcel de la Corte Superior de Justicia de Lima (2006).

${ }_{25}$ Tribunal Constitucional del Perú. Ruiz con Segunda Sala Penal de la Corte Superior de Justicia de Piura (2007). Idéntico en Chávez con Segunda Sala Penal de la Corte Superior de Justicia de Ica (2005).
} 
Ello, por cuanto, siendo los derechos fundamentales límites a la actuación del legislador, las medidas de restricción de la libertad ambulatoria, cuando no se producen a consecuencia de la imposición de una pena, quedan justificadas únicamente, como ultima ratio, en la medida en que resulten absolutamente imprescindibles y necesarias para la defensa de los bienes jurídicos fundamentales en un proceso penal y siempre que no hayan otros mecanismos menos radicales para conseguirla. Caso contrario, se produce una afectación al derecho a la libertad individual y al principio informador de presunción de inocencia". ${ }^{26}$

Ahora bien, como ejemplo de medidas cautelares que restringen el ejercicio del derecho a la libertad personal, tenemos las siguientes:

\section{A. Detención:}

"Sobre la detención personal, el artículo 20, inciso 24), literal f, de la Constitución prevé, taxativamente, la ocurrencia de dos supuestos para que ésta sea legítima: a) el mandato escrito y motivado del juez, y b) el flagrante delito. La norma constitucional precitada precisa que ambos supuestos no son concurrentes y que el plazo para que el detenido sea puesto a disposición de la autoridad pertinente es de 24 horas, con la excepción de los delitos de terrorismo, espionaje y tráfico ilícito de drogas, en cuyo caso la detención preventiva puede extenderse por 15 días. En el caso de autos, la detención responde al supuesto de flagrancia, pues el Jefe de la DIROVE consideró que la conducta del beneficiario se ajustaba a tal condición en el momento de los hechos". ${ }^{27}$

"En relación a la detención personal, el inciso 24, literal f, del citado artículo, precisa la existencia de dos situaciones en las que es legítima la detención, esto es, el mandamiento escrito y motivado del juez y, flagrante delito; las cuales serán materia de análisis por este Colegiado a efectos de establecer la existencia de la violación constitucional que sustenta la demanda”. ${ }^{28}$

\section{B. Prisión preventiva:}

"En ese sentido, este Tribunal considera que si bien la detención judicial preventiva constituye una medida que limita la libertad física, por sí misma, no es

\footnotetext{
${ }^{26}$ Tribunal Constitucional del Perú. Villanueva con Segunda Sala Penal Superior con reos libres de la Corte Superior de Justicia de Lima (2004).

27 Tribunal Constitucional del Perú. Carrión con Tercera Sala Penal de la Corte Superior de Justicia de La Libertad (2007).

${ }^{28}$ Tribunal constitucional del Perú. Delgado con Primera Sala Penal de la Corte Superior de Justicia del Santa (2004). Idéntico en Hilario con Segunda Sala Especializado en lo Penal para procesos con reos libres de la Corte Superior de Justicia de Lima (2008).
} 
inconstitucional. Esto es así porque, en esencia, la detención judicial preventiva es una medida cautelar, dado que se dicta para asegurar la efectividad de la sentencia condenatoria a dictarse en el futuro.

Del análisis de la cuestionada resolución que en copia certificada obra en autos, de fojas 27 a 33, se desprende que el juez penal no sólo ha considerado relevante que en el proceso penal existen suficientes elementos de prueba que incriminan al demandante como partícipe del delito imputado, sino también la posibilidad de que fugue o perturbe la actividad probatoria. Tales hechos justifican el dictado del mandato de detención, no existiendo, por ende, arbitrariedad del juzgador. La Sala Penal emplazada confirmó esta resolución por las mismas consideraciones.

Por consiguiente, existe una base objetiva y razonable en la decisión de los órganos judiciales emplazados para mantener el mandato de detención dictado contra el demandante. Más aún, el peligro procesal que estas instancias han advertido en el presente caso (obstrucción de la actividad probatoria e intento de fuga) hace innecesario que el juzgador busque una alternativa menos gravosa respecto a la restricción de la libertad física del demandante. Siendo así, la detención dictada contra el accionante está arreglada a derecho, no siendo de aplicación el artículo $2^{\circ}$ del Código Procesal Constitucional. ${ }^{29}$

$\mathrm{Al}$ respecto, este Tribunal ha sostenido en reiterada jurisprudencia que la detención judicial preventiva es una medida provisional que limita la libertad física, pero no por ello es, per se, inconstitucional, en tanto no comporta una medida punitiva, ni afecta la presunción de inocencia que asiste a todo procesado y, legalmente, se justifica siempre y cuando existan motivos razonables y proporcionales para su dictado. En tal sentido, tanto la resolución que decreta el mandato de detención como su confirmatoria deben cumplir con la exigencia constitucional de la motivación de las resoluciones judiciales.

El artículo 135 del Código Procesal Penal establece que para el dictado de la medida cautelar de detención es necesaria la concurrencia simultánea de tres presupuestos: a) que existan suficientes elementos probatorios de la comisión de un delito doloso que vincule al imputado como autor o partícipe del mismo (...); b) que la sanción a imponerse o la suma de ellas sea superior a un año de pena privativa de libertad (...), y c) que existan suficientes elementos probatorios para concluir que el imputado intenta eludir la acción de la justicia o perturbar la actividad probatoria. Al respecto, el Tribunal Constitucional ha señalado en la

\footnotetext{
${ }^{29}$ Tribunal Constitucional del Perú. Chávez con Segunda Sala Penal de la Corte Superior de Justicia de Ica (2005).
} 
sentencia recaída en el expediente No 1091-2002-HC/TC, caso Vicente Ignacio Silva Checa, que la justicia constitucional no es la competente para determinar la configuración de cada presupuesto legal que legitima la adopción de la detención judicial preventiva, lo cual es tarea que compete a la justicia penal ordinaria; sin embargo, sí es su atribución el verificar si estos presupuestos concurren de manera simultánea y que su imposición sea acorde a los fines y al carácter subsidiario y proporcional de dicha institución; lo que debe estar motivado en las resoluciones que se cuestiona.

En el presente caso, examinada la resolución cuestionada (fojas 2) se aprecia de la misma que no cumple con la exigencia constitucional de la motivación de las resoluciones judiciales adecuada a las condiciones legales de la materia, puesto que no expresa en sus fundamentos una suficiente justificación, descrita de manera objetiva y razonada a efectos de confirmar el mandato de detención en contra del recurrente, limitándose a señalar que "las pruebas actuadas (...) no [han] desvirtuado lo señalado anteriormente en la referencial de la menor. En consecuencia, la demanda debe ser estimada al haberse acreditado la vulneración del derecho a la motivación resolutoria, resultando de aplicación el artículo $2^{\circ} \mathrm{del}$ Código Procesal Constitucional, lo que no implica la libertad del demandante en tanto subsiste la medida cautelar de la libertad decretada en el auto de apertura de instrucción, pronunciamiento judicial que no ha sido materia de cuestionamiento ni de análisis constitucional". ${ }^{30}$

\section{Arresto domiciliario:}

"El Tribunal Constitucional en reiterada jurisprudencia ha señalado que la detención domiciliaria y la prisión preventiva responden a medidas de diferente naturaleza jurídica, en razón al distinto grado de incidencia que generan sobre la libertad personal del individuo.

No cabe duda, que la detención domiciliaria supone una intromisión a la libertad menos gravosa, pues resulta una menor carga psicológica, debido a que no es lo mismo, permanecer por disposición judicial en el domicilio que en prisión, siendo menos estigmatizante y evitando el 'contagio criminal' al que se expone con la entrada a un establecimiento penitenciario. Sin embargo, no se puede desconocer que tanto la prisión provisional y la detención domiciliaria, se asemejan por el objeto, es decir, en tanto impiden a una persona autodeterminarse por su propia voluntad a fin de lograr asegurar la eficacia en la administración de justicia.

\footnotetext{
${ }^{30}$ Tribunal Constitucional del Perú. Ruiz con Segunda Sala Penal de la Corte Superior de Justicia de Piura (2007).
} 
En la legislación vigente, la detención domiciliaria se ha considerado dentro de las medidas de comparecencia -siendo la más gravosa de todas-; y como tal, esta medida o aquellas de comparecencia menos gravosas, se aplican en defecto de la detención preventiva cuando no se configuren algunos de los presupuestos de ley establecidos para decretarla.

La detención domiciliaria, en tanto restricciones a la libertad individual anterior a la imposición de la pena, únicamente procede como medida cautelar cuando asegure un eficiente desarrollo del proceso penal. A ese respecto, el Tribunal Constitucional ha establecido en uniforme jurisprudencia los presupuestos básicos para la imposición del arresto domiciliario, cuales son: a) fumus boni iuris (apariencia del derecho); b) periculum in mora (peligro procesal).

El primero de ellos, referido a la suficiencia de elementos probatorios que vinculen al imputado con el hecho delictivo, mientras que el segundo se relaciona con el peligro de que el procesado se sustraiga a la acción de la justicia o perturbe la actividad probatoria. (Exp. No 0124-2004-HC, Exp. No 2712-2002-HC).

Asimismo, al igual que en el caso de la prisión preventiva, la detención domiciliaria, se encuentra sometida a los criterios subsidiariedad, provisionalidad, razonabilidad y proporcionalidad, a fin de evitar la arbitrariedad de la decisión.

En ese sentido, si bien las restricciones a derechos son admitidas prima facie, el principio de proporcionalidad -también conocido como prohibición del exceso-, impide la injerencia desproporcionada sobre los mismos, evaluación que debe medirse en conjunto con otro límite, cual es, la prohibición de rebasar el contenido esencial del derecho". ${ }^{31}$

\section{Internamiento en un centro psiquiátrico:}

"En nuestro ordenamiento, las penas tienen una naturaleza muy distinta con respecto a las medidas de seguridad. Así, mientras que la pena constituye la sanción tradicional que caracteriza al Derecho penal y es un mal con el que éste amenaza en el caso de que se realice un acto considerado como delito; las medidas de seguridad no suponen la amenaza de un mal en el caso de que se cometa un delito. Las medidas de seguridad 'no suponen la amenaza de un mal en el caso de que se cometa un delito, sino un tratamiento dirigido a evitar que un sujeto peligroso llegue a cometerlo. Mientras que la pena se inflige por un delito cometido, la medida de seguridad se impone como medio de evitarlo'. No obstante, desde la perspectiva del Derecho constitucional, la medida de internación no sólo se justifica porque persigue evitar la comisión de futuros delitos, sino también porque su finalidad es la recuperación de la persona. Y no puede ser de otro modo,

\footnotetext{
${ }^{31}$ Tribunal Constitucional del Perú. Villanueva con Segunda Sala Penal Superior con reos libres de la Corte Superior de Justicia de Lima (2004).
} 
pues nuestra Constitución (artículo $1^{\circ}$ ) establece que la persona y la protección de su dignidad son el fin supremo de la sociedad y del Estado, condición que no se pierde por el hecho de haber sido condenado o, como en el presente caso, por haber sido sometido a una medida de seguridad.

Por consiguiente, es una exigencia constitucional que, a fin de que dicha medida cumpla su finalidad, la persona sea internada en un centro especializado que cuente con la adecuada atención profesional. Sin embargo, las medidas de seguridad -internación y tratamiento ambulatorio- no pueden ser impuestas por el juez penal con absoluta y entera discrecionalidad; antes bien, para que una medida de seguridad sea constitucionalmente legítima, ésta debe dictarse dentro de los límites que la ley prevé y en estricta observancia del principio de proporcionalidad. Por ello, de acuerdo con nuestro ordenamiento (artículo 72 del Código Penal) deben concurrir, en el dictado de las medidas de seguridad, las siguientes circunstancias: a) que el agente haya realizado un acto previsto como delito, y b) que del hecho y de la personalidad del agente puede deducirse un pronóstico de comportamiento futuro que revele una elevada probabilidad de comisión de nuevos delitos. Pero también las medidas de seguridad están sujetas, como ya se ha señalado, a la observancia del principio de proporcionalidad; en consecuencia, tales medidas 'deben ser proporcionales a la peligrosidad delictual del agente, la gravedad del hecho cometido y los que probablemente cometiera si no fuese tratado' (artículo 73 del Código Penal).

Dado que la medida de internación consiste en el ingreso y tratamiento del inimputable en un centro hospitalario u otro establecimiento adecuado, con fines terapéuticos o de custodia, tal ingreso no puede ser por un tiempo indefinido sino limitado, motivo por el cual se ha previsto que 'la duración de la medida de internación no podrá exceder el tiempo de duración de la pena privativa de libertad que hubiera correspondido aplicarse por el delito cometido' (artículo 75 del Código Penal). Por otro lado, la imposición de la medida de internación comporta una facultad para el juez que la dictó y un deber para la autoridad del centro en el cual se encuentra internada la persona. El juez penal puede solicitar, cada seis meses, a la autoridad del centro de internación un peritaje a fin de conocer si las causas que dieron lugar al dictado de la medida de internación han desaparecido. Sin perjuicio de ello, la autoridad del centro de internación está obligada a remitir dicho peritaje, al margen de que el Juez la solicite o no (artículo 75 del Código Penal)".32

\footnotetext{
${ }^{32}$ Tribunal Constitucional del Perú. Mallma con Segunda Sala Especializada en lo Penal para procesos con reos en cárcel de la Corte Superior de Justicia de Lima (2006).
} 


\section{E. Impedimento de salida:}

"La medida provisional personal de impedimento de salida del país no tiene una regulación propia en el Código de Procedimientos Penales de 1940, pero sí en el Nuevo Código Procesal Penal conforme lo establecen los artículos 295 y 296, respectivamente. De igual modo se encuentra regulada por el artículo $2^{\circ}$, inciso 2), de la Ley No 27.379 que señala que esta medida coercitiva se adoptará en tanto resulte indispensable para los fines del proceso y siempre que no sea necesaria una limitación más intensa de la libertad personal. Cabe precisar que con esta intervención no se afecta en estricto a la libertad personal, sino, como dijimos supra, a la libertad de tránsito, ambas conformantes de la libertad individual. De ahí que cualquier persona nacional o extranjera, no estando detenida, esto es, gozando plenamente de su derecho a la libertad personal, se vea impedida de transitar libremente por el territorio nacional y a salir de él y entrar en él.

Conviene puntualizar que no toda intervención a un derecho fundamental per se resulta inconstitucional, pero sí puede resultarlo cuando la misma no se ajuste plenamente al principio de proporcionalidad. $\mathrm{Y}$ es que si bien, es atribución del juez penal dictar las medidas coercitivas pertinentes a fin de asegurar el normal desarrollo y fines del proceso, y por tanto, puede imponer el impedimento de salida del país, dicha medida coercitiva -con independencia de la nueva normativa procesal penal- debe reunir, por lo menos, los siguientes requisitos:

a) Debe ser ordenada, dirigida y controlada por autoridad judicial. Lo que significa que sólo mediante decisión judicial se puede imponer la medida provisional personal de impedimento de salida del país.

b) La decisión judicial debe contener los datos necesarios de la persona afectada. Lo que supone que dicha decisión mínimamente debe contener los nombres y apellidos completos de la persona afectada; el número de su Documento Nacional de Identidad; el órgano jurisdiccional que lo dispone; el número o identificación del expediente y el delito por el cual se le investiga o procesa. Estos mismos requisitos deben ser registrados por la autoridad administrativa competente.

c) Debe estar debidamente fundamentada y motivada. Lo que significa que deben señalarse las razones o motivos que supuestamente justifican la imposición de dicha medida, y en su caso, de la prolongación de su mantenimiento mientras dure el proceso.

d) Debe señalarse la duración de la medida. Si bien la norma preconstitucional no señala un plazo de duración del impedimento de salida del país; ello no obsta para que el juez de la causa, en cada caso concreto, señale un plazo determinado, o de ser el caso, establezca la prolongación de su mantenimiento mientras dure el proceso; en este último caso, deberá ser dictado razonablemente 
atendiendo a las necesidades que existan al interior de cada proceso, tales como el asegurar la presencia del imputado en el proceso, el normal desarrollo del mismo, el evitar que se perturbe la actividad probatoria y la efectividad de las sentencias.

En cualquier caso, esta medida no puede durar más allá de lo que puede durar el proceso penal, pues, existiendo sentencia condenatoria con mandato de detención no hay razón alguna para mantener su vigencia. O más aún, si se trata de procesos fenecidos con sentencia absolutoria o de un sobreseimiento, resultará totalmente arbitrario que dicha medida subsista.

El impedimento de salida del país es una medida coercitiva personal adicional a la de comparecencia con restricciones, en cuanto que también está destinada a asegurar la vigencia y eficacia de la comparecencia restringida (evitando la fuga del imputado). Pues, tal como ha señalado la doctrina procesal penal, el impedimento de salida del país, si bien no supone la posibilidad absoluta de evitar la posible fuga, sí la hace más difícil, y por ende, la disminución en el riesgo de fuga, pues, en tales condiciones, el imputado verá dificultada su intención de huir al extranjero, y más aún, la de subsistir y trabajar en el otro país. Asimismo, esta medida provisional personal puede ser acumulada a la detención preliminar; pero no resulta preciso que pueda adicionarse a la detención preventiva, mucho menos a la de mandato de comparecencia simple.

Por último, si bien la comparecencia restringida permite mantener en libertad al procesado, ello no puede conllevar una renuncia por parte del juez sobre la necesidad de garantizar la presencia del imputado en el proceso y la efectividad de las sentencias. De ahí que se haga necesaria la imposición del impedimento de salida del país en los casos en que exista un riesgo no grave de fuga o de perturbación de la actividad probatoria, pues, si lo que en realidad existe es un peligro procesal grave e inminente, lo que corresponde en tal caso no es en puridad el impedimento de salida adicionada al mandato de comparecencia con restricciones, sino el mandato de detención, esto último, bajo la premisa de que cuanto mayor sea el riesgo, mayor ha de ser la intensidad de la intervención, empero, siempre sujeta al principio de proporcionalidad". ${ }^{33}$

\section{F. No hay prisión por deudas:}

"Precisamente, uno de los límites al derecho fundamental a la libertad personal es el que está previsto en el artículo $2^{\circ}$, inciso 24, literal "c", de la Constitución

\footnotetext{
${ }^{33}$ Tribunal Constitucional del Perú. Victorio con Primera Sala Especializada en lo Penal para procesos con reos libres de la Corte Superior de Justicia de Lima (2008).
} 
Política. Tal artículo, si bien recoge como uno de los contenidos constitucionalmente garantizados de la libertad y seguridad personales, que no hay prisión por deudas, ello no excluye que este principio se vea limitado por un mandato judicial por incumplimiento de deberes alimentarios. Al respecto, este Tribunal Constitucional (Exp. No 2982-2003-HC/TC, Exp. No 2088-2004-HC/TC) ha establecido que cuando la citada disposición constitucional prohíbe la prisión por deudas, con ello se garantiza que las personas no sufran una restricción de su derecho fundamental a la libertad personal por el incumplimiento de obligaciones originadas en relaciones de orden civil.

En nuestro ordenamiento constitucional, en principio, no cabe la prisión por deudas. Sin embargo, nuestra propia Ley Fundamental ha establecido una excepción a dicha regla, esto es, en el caso del incumplimiento de deberes alimentarios. Ello tiene su fundamento en que, en tales casos, están de por medio, no cuestiones pecuniarias o materiales, sino la tutela de los derechos fundamentales como la dignidad de la persona humana, la vida, la salud y la integridad física y psicológica del alimentista. Esta es la razón por la cual, de acuerdo con la Constitución, el juez, en este supuesto, tiene la facultad y la competencia para ordenar la restricción del derecho a la libertad personal del obligado.

Ahora bien, en el caso concreto, el demandante alega que en la actualidad se encuentra delicado de salud y además imposibilitado de seguir pasando una asignación de alimentos. Este Colegiado advierte de autos que contra el demandante se ha seguido un proceso penal, signado con el expediente No 2004-643, por el delito de omisión de obligación alimentaria, como consecuencia del incumplimiento de las obligaciones devengadas liquidadas en el proceso civil de alimentos No 2001-357. Además, en autos (a fojas 280) obra la sentencia del Juzgado Penal de la Provincia de Chanchamayo, su fecha, 19 de setiembre de 2005, mediante la cual se condena al demandante a dos años de pena privativa de la libertad". 34

Finalmente, y ello es el tema central del presente apartado, nos vamos a centrar en la figura de la detención.

\subsubsection{Concepto de detención}

En primer lugar, existe un concepto lato de la detención, entendida como cualquier forma de obstaculizar la libertad de la persona; es decir, las situaciones fácticas

\footnotetext{
${ }^{34}$ Tribunal Constitucional del Perú. Yupanqui con Segunda Sala Mixta Descentralizada de La Merced (2006).
} 
en las que se impide a la persona la autodeterminación de la conducta lícita, como por ejemplo, parar a una persona en la calle para verificar su identidad.

Un segundo concepto de detención también amplio, pero menos que el anterior, entendería por tal toda privación -entendida como encierro, es decir, con una duración mínima- de libertad de una persona; así entendida, sería detención, por ejemplo, un encierro en un centro psiquiátrico.

Por último, un tercer concepto, más técnico y estricto, de detención equipara ésta a la detención policial, por decisión autónoma o por orden judicial, preordenada a la imputación de un delito en un proceso penal.

Naturalmente, si se acoge el primer concepto de detención, que equipara ésta a toda situación en que se limita o restringe la libertad o se priva de ella, sería del todo cierto que no existe más que una alternativa, libertad o detención. Sin embargo, la doctrina utiliza generalmente el concepto técnico de detención, el consistente en la detención policial o judicial por comisión de un delito, y en este caso, como en el intermedio, sí existen otros supuestos de privación o restricción de libertad distintos a la detención (García, 1995, p. 78).

Asimismo, este concepto ha sido asumido por el Tribunal Constitucional del Perú de la forma siguiente: "Cabe precisar que el inciso 24 del artículo 2 de la Constitución Política del Perú consagra que la libertad personal, como todo derecho fundamental, no es un derecho absoluto, pues su ejercicio se encuentra regulado y puede ser restringido mediante ley, precisando la existencia de dos situaciones en las que es legítima la detención: el mandamiento escrito y motivado del juez, y la comisión de flagrante delito. Asimismo, según lo ha establecido este Tribunal en reiterada jurisprudencia, para declarar un delito flagrante deben concurrir dos requisitos: a) la inmediatez temporal, es decir, que el delito se esté cometiendo o que se haya cometido instantes antes; b) la inmediatez personal, que el presunto delincuente se encuentre en el lugar, en ese momento, en dicha situación; y, con relación al objeto o a los instrumentos del delito, que ello ofrezca una prueba evidente de su participación en el hecho delictivo". ${ }^{35}$

En ese sentido, nos vamos a centrar al análisis de uno de los supuestos de la detención, esto es, por flagrancia delictiva.

35 Tribunal Constitucional del Perú. Sarmiento con Primera Sala Especializada en lo Penal de la Corte Superior de Justicia de Lambayeque (2005). 


\subsection{Detención por flagrancia delictiva}

\section{Esta figura está prevista en el artículo 283 del Código Procesal Penal Federal argentino; ${ }^{36}$ en el artículo 227 del Código de Procedimiento Penal de Bolivia; ${ }^{37}$ en el artículo 235 del Código Procesal Penal de Costa Rica; ${ }^{38}$ artículo 161 del Código de Procedimiento Penal de Ecuador; ${ }^{39}$ artículo 231 del Código Procesal}

${ }^{36}$ Artículo 283.- "Los funcionarios y auxiliares de la policía tienen el deber de detener, aun sin orden judicial: 10) Al que intentare un delito de acción pública reprimido con pena privativa de libertad, en el momento de disponerse a cometerlo.

20) Al que fugare, estando legalmente detenido.

3o) Excepcionalmente a la persona contra la cual hubiere indicios vehementes de culpabilidad, y exista peligro inminente de fuga o de serio entorpecimiento de la investigación y al solo efecto de conducirlo ante el juez competente de inmediato para que resuelva su detención, y

4º) A quien sea sorprendido en flagrancia en la comisión de un delito de acción pública reprimido con pena privativa de libertad.

Tratándose de un delito cuya acción dependa de instancia privada, inmediatamente será informado quien pueda promoverla, y si éste no presentare la denuncia en el mismo acto, el detenido será puesto en libertad".

${ }^{37}$ Artículo 227.- "La Policía Nacional podrá aprehender a toda persona en los siguientes casos:

1. Cuando haya sido sorprendida en flagrancia;

2. En cumplimiento de mandamiento de aprehensión librado por juez o tribunal competente;

3. En cumplimiento de una orden emanada del fiscal, $y$,

4. Cuando se haya fugado estando legalmente detenida.

La autoridad policial que haya aprehendido a alguna persona deberá comunicar y ponerla a disposición de la Fiscalia en el plazo máximo de ocho horas".

${ }^{38}$ Artículo 235. "Las autoridades de policía podrán aprehender a toda persona, aun sin orden judicial, cuando: a) Haya sido sorprendida en flagrante delito o contravención o sea perseguida inmediatamente después de intentarlo o cometerlo.

b) Se haya fugado de algún establecimiento penal o de cualquier otro lugar de detención.

c) Existan indicios comprobados de su participación en un hecho punible y se trate de un caso en que procede la prisión preventiva.

Asimismo, en caso de flagrancia, cualquier persona podrá practicar la aprehensión e impedir que el hecho produzca consecuencias. La persona aprehendida será entregada inmediatamente a la autoridad más cercana.

La autoridad policial que haya aprehendido a alguna persona deberá ponerla, con prontitud, a la orden del Ministerio Público, para que éste, si lo estima necesario, solicite al juez la prisión preventiva. La solicitud deberá formularse luego de realizar las diligencias indispensables y, en todo caso, dentro de las veinticuatro horas contadas a partir de la captura.

Si se trata de un delito que requiera la instancia privada, será informado inmediatamente quien pueda instar y, si éste no presenta la denuncia en el mismo acto, el aprehendido será puesto en libertad".

${ }^{39}$ Artículo 161.- "Los agentes de la Policía Judicial o de la Policía Nacional pueden aprehender a una persona sorprendida en delito flagrante de acción pública o inmediatamente después de su comisión; y la pondrán a órdenes del juez competente dentro de las veinticuatro horas posteriores. En caso del delito flagrante, cualquier persona está autorizada a practicar la aprehensión, pero debe entregar inmediatamente al aprehendido a la policía y ésta, a su vez, al juez competente". 


\section{Penal de Nicaragua; ${ }^{40}$ artículo 239 del Código Procesal Penal de Paraguay; ${ }^{41}$ artículo 259 del Código Procesal Penal del Perú ${ }^{42}$.}

La detención por flagrancia delictiva, según Ortells Ramos, "es la privación de libertad realizada por la Policía, de duración determinada por la ley, practicada con el fin de poner a una persona a disposición del Juez, para que pueda ser ejecutada la detención judicial que, en su caso, se acuerde" (Ortells, 1978, p. 439).

\footnotetext{
${ }^{40}$ Artículo 231.- "Procederá la detención por la Policía Nacional, sin necesidad de mandamiento judicial, cuando el autor del hecho punible sea sorprendido en el momento de cometerlo, sea perseguido huyendo del sitio del hecho o se le sorprenda en el mismo lugar o cerca de él con armas, instrumentos u otros objetos que de alguna manera hagan presumir su participación inmediata en el hecho.

En los casos de flagrancia previstos en el párrafo anterior, cualquier particular podrá proceder a la detención, siempre que el delito amerite pena privativa de libertad. Acto seguido deberá entregar al aprehendido a la autoridad más cercana.
}

Los jefes de las delegaciones de la Policía Nacional, bajo su responsabilidad personal, podrán emitir orden de detención, con expresión de las razones que la hagan indispensable, contra quienes haya probabilidad fundada de la comisión de un delito sancionado con pena privativa de libertad, dentro de las doce horas de tener conocimiento del hecho. Sin embargo, estos casos no serán considerados como de persecución actual e inmediata de un delincuente para efecto de allanamiento de domicilio. En los demás casos, se requerirá de mandamiento judicial para proceder a la detención. Cuando se produzca la detención de una persona, los funcionarios policiales deberán informar en un término no superior a las doce horas al Ministerio Público de las diligencias efectuadas $y$ presentar en el plazo constitucional al imputado ante el juez competente.

En el plazo de doce horas referido en el párrafo anterior no se incluirá el tiempo necesario para establecer la comunicación con el Ministerio Público".

${ }^{41}$ Artículo 239.- "La Policía Nacional podrá aprehender a toda persona comprendida dentro de los siguientes casos, aun sin orden judicial:

1) cuando sea sorprendida en flagrante comisión de hecho punible o cuando sea perseguida inmediatamente después de su comisión; se entenderá que existe flagrancia cuando el autor del hecho punible sea sorprendido en el momento de intentarlo o cometerlo, o inmediatamente después, o mientras es perseguido por la fuerza policial, por la víctima o por un grupo de personas;

2) cuando se haya fugado de algún establecimiento penal o de cualquier otro lugar de detención; y,

3) cuando existan suficientes indicios de su participación en un hecho punible y se trate de casos en los que procede la detención preventiva.

Asimismo, en caso de flagrancia, cualquier persona podrá practicar la aprehensión e impedir que el hecho punible produzca consecuencias. La persona aprehendida será entregada, inmediatamente, a la autoridad más cercana.

La autoridad policial que haya aprehendido a alguna persona lo deberá comunicar, dentro de las seis horas, al Ministerio Público y al juez".

${ }^{42}$ Artículo 259.- "La Policía detendrá, sin mandato judicial, a quien sorprenda en flagrante delito. Existe flagrancia cuando la realización del hecho punible es actualy, en esa circunstancia, el autor es descubierto, o cuando es perseguido y capturado inmediatamente de haber realizado el acto punible o cuando es sorprendido con objetos o huellas que revelen que acaba de ejecutarlo.

Si se tratare de una falta o de un delito sancionado con una pena no mayor de dos años de privación de libertad, luego de los interrogatorios de identificación y demás actos de investigación urgentes, podrá ordenarse una medida menos restrictiva o su libertad". 
Para San Martín Castro, "la detención por flagrancia delictiva constituye una potestad de la policía, pues a ella prima facie le corresponde apreciar los presupuestos legales de su imposición. Se trata, sin embargo, de una potestad orientada al cumplimiento de los fines de un proceso penal a cargo del Órgano Jurisdiccional y es, en todo caso, una consecuencia del carácter de competencia o prevención que corresponde a los poderes policiales. Como excepción al principio de jurisdiccionalidad previa, puede ser acordada y practicada sin un precedente mandato judicial" (San Martín, 1999, p. 804).

Gimeno Sendra comenta que "la detención preliminar policial es una medida cautelar, porque es realizada en función de la incoación de un proceso penal, preordenada a garantizar la futura aplicación del ius puniendi y, de modo inmediato, a proporcionar al Juez el primer sustrato fáctico para el inicio de la instrucción formal y la adopción, en su caso, de las medidas cautelares que correspondan" (Gimeno, 1997, p. 354).

La detención en casos de delitos flagrantes constituye una situación sumamente singular, respecto a la regla representada por el general respeto y protección que depara nuestra ley a la libertad personal, y la excepción, constituida por la detención mediando orden judicial escrita y debidamente fundamentada.

La detención policial consiste en la privación de la libertad ambulatoria de una persona realizada por la Policía. En tal sentido, cabe entenderla como una obligación que tienen los miembros de la policía para privar de la libertad a persona imputada de un delito en atención a los presupuestos que exige la Constitución y las leyes. Al respecto, para Sánchez Velarde "el mandato de autoridad judicial y el caso de flagrante delito, no existe otra forma legal de proceder a la detención por la autoridad policial. No hay detención por sospecha o por indocumentado, en cuyos casos se deberá procurar superar el estado de sospecha o establecer mediante las fórmulas más rápidas la identidad de la persona intervenida” (Sánchez, 2004, p. 821).

Igualmente, se le denomina también "detención gubernativa", en tanto la práctica hace que la policía dependa del Ministerio del Interior y, por ende, del Poder Ejecutivo. Podemos recordar, en este sentido, que al iniciarse la República y no existiendo aún la policía, la detención la ordenaban y practicaban otros representantes del Ejecutivo, tales como el Prefecto, el Intendente o el Gobernador (Angulo, 2002, p. 101).

La facultad concedida al personal policial para efectuar la detención de las personas, cuando son sorprendidas flagrantemente en la comisión de ilícitos penales, en el Derecho Comparado posee, casi en la generalidad de los casos, 
rango constitucional. ${ }^{43}$ Esto obedece al principio de restricción de los casos en que puede afectarse la libertad de las personas, conforme al cual debe considerarse la inexistencia de zonas intermedias entre lo aceptado en la ley como detención legítima y el ejercicio de la libertad.

La detención policial puede ser definida como aquella medida cautelar y provisional por la que los miembros de las Fuerzas y Cuerpos de Seguridad del Estado privan de libertad a una persona, sobre la que pueda presumirse su participación en un hecho delictivo, durante el tiempo indispensable para practicar las diligencias de reconocimiento e interrogatorio y dentro del plazo previsto en la ley, poniéndola en libertad o a disposición de la autoridad judicial.

La detención policial no sólo significa la necesaria reacción inmediata del Estado frente al delito y el delincuente, en procura de ofrecer seguridad a los ciudadanos agraviados en su derecho, evitando prima facie la indeseable aparición de la justicia por mano propia, sino la posibilidad de efectuar una debida identificación del autor del hecho; poder recuperar los bienes sustraídos, en su caso; llevar al detenido ante la autoridad fiscal o judicial competente, de ser ello necesario; colocando a los órganos jurisdiccionales, finalmente, merced a los elementos probatorios e indicios recogidos en la mejor condición posible para administrar justicia.

Por otro lado, dos son los presupuestos para la ejecución de este tipo de detención: a) delito flagrante y b) temporalidad.

\section{A. Delito flagrante}

Hemos de comenzar este epígrafe manifestando que se va a prescindir aquí en todo caso de elaborar una teoría general sobre la flagrancia, ya que este concepto puede hacer referencia a cosas distintas según sea, por ejemplo, el presupuesto para proceder a una detención, del ejercicio de la legítima defensa o para la aplicación de un determinado procedimiento -como es el proceso inmediato regulado en el Código Procesal Penal peruano.

Nos limitaremos al estudio del concepto procesal, ciñéndonos en su interpretación a la situación que se exige como previa para poder proceder a la detención.

En esa inteligencia, la palabra flagrante proviene, según Joan Corominas, del latín flagrans, flagrantis; participio activo de flagare: arder. Como adjetivo, la palabra flagrante define a lo que se está ejecutando actualmente. En flagrante: es un modo adverbial que significa "en el mismo acto de estarse cometiendo un delito" y equivale a infraganti. La locución "in fraganti crimine" de la que deviene

\footnotetext{
${ }_{43}$ Brasil, artículo 5, numeral LX; Chile, artículo 19, inciso 7, letra c); Colombia, artículo 32; Costa Rica, artículo 37; Ecuador, artículo 24, inciso g); Nicaragua artículo 33, inciso 1; Panamá, art. 21; Paraguay, artículo 12; Uruguay, artículo 15; Venezuela, artículo 44, inciso 1.
} 
el uso actual de infraganti, resulta antigua, pues ya figuraba en 533 en el Código de Justiniano.

En España aparece registro de la palabra flagrante en 1444. Modernamente, se habla de flagrante delito o delito flagrante o simplemente de flagrancia, y así nada más, se comprende la alusión al "delito que se está ejecutando en el momento que resulta sorprendido su autor". En el caso peruano la flagrancia, histórica y normativamente, aparece en el artículo 119 de la Constitución de 1826.

En alguna oportunidad Escriche pudo entender que el delito flagrante era el que se cometió públicamente, y por ello, fue visto por muchas personas (Momethiano, 2001, p. 98). Actualmente, como veremos en seguida, el concepto de lo flagrante identifica solamente a lo notorio (como el inglés flagrant) de la autoría; esto es que, con seguridad meridiana, un hecho ilícito puede ser atribuido a una o varias personas en particular, en razón de haberse observado cuando se incurrió en aquél o por accederse a percibir claras evidencias de la actuación ilícita concreta. Obvio es que la suficiencia, respecto de la relación de causalidad (hecho-autor) a que se alude, se entiende en términos del conocimiento común y no en los términos técnico-jurídicos que se desprenden de una sentencia judicial.

Así es que hoy existen tres conceptuaciones en que se identifica la existencia de flagrancia. Respecto a la antigüedad de estas formas de entender la flagrancia, podemos identificar a la vertiente italiana, en que citando a Franco Cordero, podríamos establecer que "los códigos anteriores a la unificación de Italia distinguían entre el hecho de sorprender a la persona en el momento de la comisión del delito y otras circunstancias semejantes próximas, en las cuales el delito es un acontecimiento que está muy cerca, por ejemplo, cuando el autor está siendo perseguido, o también cuando lo indiquen señales o huellas muy recientes" (Cordero, 2000, p. 408).

A este respecto, el mismo citado autor recuerda que Romagnosi expresó: "Es delito flagrante que no sea sorprendido cuando comete el hecho, o cuando sea perseguido por el ofendido o también por los 'gritos del pueblo', y constituye un caso semejante el que, en tiempo y lugar próximos, lleve consigo los efectos, armas, instrumentos, papeles o también señales que sirvan para hacerlo presumir razonablemente autor".

En República Dominicana, en el artículo 41 del Código de Procedimiento Criminal, se conceptúa así la flagrancia: "Se comete en la actualidad o acaba de cometerse. Se reputa también flagrante delito, el caso en que el inculpado sea acusado por el clamor público, y el que se halle con objetos, armas, instrumentos o papeles que hagan presumir ser el autor o cómplice del delito; con tal que esto suceda en un tiempo próximo o inmediato al del delito". 
En México, en el Código Federal de Procedimientos Penales, Capítulo IV del Título V, artículo 193, se contemplan los casos de flagrancia. En la última reforma, se indica que entre quienes se podría señalar como el presunto autor del hecho delictivo estaría inclusive su cómplice. Igualmente, al hecho de que pueda encontrarse en poder del inculpado instrumento o producto del delito, se le suma la posibilidad de que aparezcan huellas o indicios que hagan presumir fundadamente su participación en el mismo.

En Colombia, reconociendo formalmente la realidad de las expresiones de la flagrancia, en el artículo 370 del Código Procesal Penal se lee:

"Tenemos que hay flagrancia cuando la persona es sorprendida en el momento de cometer un hecho punible o cuando es sorprendida con objetos, instrumentos o huellas, de los cuales aparezca fundadamente que momentos antes ha cometido un hecho punible o participado en él o cuando es perseguida por la autoridad o cuando por voces de auxilio se pide su captura".

Iguales manifestaciones de la flagrancia han sido reconocidas en la jurisprudencia española. Resulta ilustrativa, en tal sentido, la sentencia del Tribunal Constitucional Español No 341/1993, de 18 de noviembre, citada por el profesor César San Martín, la misma que a la letra dice: "A los efectos constitucionales resulta inexcusable reconocer la arraigada imagen de la flagrancia como situación práctica en la que el delincuente es sorprendido -visto directamente o percibido de otro modo- en el momento de delinquir o en circunstancias inmediatas a la perpetración del delito..." (San Martín, 1999, p. 806).

En el caso peruano, no existen parámetros claros respecto a lo que corresponde entender como flagrancia, subsistiendo interpretaciones amplias, restrictivas e intermedias; asimismo, la misma jurisprudencia no ha desarrollado el comprender la situación de flagrancia y sus elementos o requisitos (Jiménez, 2000, p. 115. Oré, 1999, p. 346).

Por otro lado, existen clases de flagrancia, las cuales son:

- La flagrancia tradicional estricta. Las ideas de descubrimiento, sorpresa y percepción sensorial del hecho delictivo han ocupado siempre un primer plano en la noción de delito flagrante; partiendo que todo hecho delictivo pasa por una fase de ejecución, sólo puede, sin embargo, ser detenido el delincuente in fraganti si un tercero percibe a través de los sentidos-descubre- que esa persona está cometiendo o acaba de cometer un delito.

Nuestra legislación, como la de muchos países, hace depender la configuración de la flagrancia de la aparición de uno o más integrantes de la policía o bien algún particular en las precisas circunstancias en que se ejecuta la comisión de un ilícito penal. 
En esa inteligencia, debemos de resaltar que el conocimiento evidente de los hechos que no haya sido adquirido a través de la percepción sensorial directa de los mismos no puede constituir una situación de flagrancia delictiva; todo lo más pueden ser indicios racionales y vehementes de que se está cometiendo un hecho delictivo, pero esta circunstancia no habilita por sí misma para la práctica de una detención.

Así, la literatura alemana a la hora de interpretar el $\$ 127$ I StPO, que permite a cualquiera la detención del sorprendido en flagrancia - "auffrischer Tat betroffen oder verfolgt"- destaca la idea de sorprender o descubrir al autor y la necesidad de que exista una apreciación o percepción a través de los sentidos de la comisión del hecho delictivo.

En cuanto a la detención en flagrancia en el ordenamiento italiano, para considerar un delito flagrante no basta con que se esté cometiendo actualmente, pues lo serían todos en el momento en que se ejecutan; lo decisivo es la percepción de la comisión del mismo por un tercero. Santoro explica de forma muy gráfica la distinción: un cadáver del que fluye sangre o una casa que se incendia no son situación de flagrancia, sólo lo será si un sujeto es sorprendido en la comisión de un delito. El actual artículo 382 del CPP italiano sí hace alusión al acto de soprender: chi viene colto nell'atto di commettere il reato.

Finalmente, el Tribunal Constitucional del Perú, ha señalado lo siguiente: "Así se tiene de la declaración del demandando a fojas 8 y del atestado policial obrante a fojas 53, que el día 14 de marzo se suscitó un incidente entre el personal de la DIROVE y dos personas, en el marco de un seguimiento policial por la presunta comisión de delito de extorsión; incidente en medio del cual resultó herido un agente policial, y en el que ambos detenidos sindicaron al beneficiario como autor intelectual del hecho delictivo, por lo que el personal policial procedió a su captura a horas 09:30 del día 15 de marzo de 2006, es decir, casi 10 horas después de suscitados los hechos delictivos. Asimismo, al momento de efectuársele el acta de registro personal se le incautaron 4 envoltorios conteniendo pasta básica de cocaína.

De lo antes expuesto resulta evidente para este Colegiado que no consta de modo objetivo que la detención del beneficiario haya sido consecuencia de que contra él exista un mandato judicial escrito y motivado, ni tampoco que hubiese sido capturado en una situación de flagrante delito; sino que por el contrario y conforme se colige de los propios documentos policiales que en copias certificadas obran en el expediente, su captura se produjo muchas horas después de producido el hecho delictivo, sin que exista inmediatez alguna de tipo temporal o personal en la comisión del delito. 
Sin embargo resulta pertinente hacer la salvedad de que, si bien la detención del beneficiario no cumplió con los requisitos concurrentes establecidos en la Norma Suprema respecto de los delitos de extorsión y de lesiones por arma de fuego, en cambio sí concurrió la flagrancia respecto del delito de tráfico ilícito de drogas, pues se tiene del acta de registro personal, obrante a fojas 20 del principal, que al actor se le halló en posesión de pasta básica de cocaína”. ${ }^{44}$

- La flagrancia material. Llamada también cuasi-flagrancia (desde el punto de vista de la aparición posterior a la comisión del hecho ilícito del integrante o los integrantes de la Policía) en sí no es una "casi flagrancia", sino que constituye flagrancia en sí, puesto que el autor o los autores son descubiertos durante la ejecución del hecho o al consumarlo, sea por el agraviado, familiares, amigos o terceros en general, que inician la persecución del autor o los autores, y hasta puede que consigan aprehenderlos; circunstancias, cualquiera de las dos, en que ingresa a escena la policía.

De lo dicho resulta que en el caso en comento aparece nítida la ocurrencia de la flagrancia, sólo que quien sorprende al agente y actúa persiguiéndole inicialmente no es el agente captor; pero, sí aparece éste, circunstancialmente o por acudir ante un llamado, mientras se lleva a cabo, en solución de continuidad, una reacción legítima ante el evento delictivo, como es la persecución o, finalmente, la captura.

Resulta claro suponer que para que los miembros de la institución policial continúen la persecución deben u observar una situación rápidamente identificable, desde el sentido común, como veraz y razonable, o recibir coherente y creíble noticia de la misma. Por tanto, desde la persona del policía, hacia el hecho delictivo se da una cercanía o proximidad, mas no necesariamente una inmediatez temporal, pues esta última debe presentarse, en todo caso, entre la circunstancia de la persecución observada por la policía o la captura y la consiguiente intervención de sus integrantes. Nos ayuda a esclarecer esto Julio Casares, quien en su Diccionario Ideológico expresa que inmediatez se refiere a lo que sucede de modo contiguo, muy cercano, muy pronto o enseguida.

El policía en este caso resulta habilitado para detener no por la observación del hecho ilícito, sino por la observación de la persecución que inician, efectúan o terminan los particulares o por la captura que podría o no haber observado (en tanto desenlace o parte final de la persecución).

Es decir, la inmediatez, continuidad o cercanía ocurre a partir del hecho de la persecución o captura del agente. Podría existir inmediatez personal, en el

\footnotetext{
${ }^{44}$ Tribunal Constitucional del Perú. Carrión con Tercera Sala Penal de la Corte Superior de Justicia de La Libertad (2007).
} 
sentido que el policía pudiera haber observado al perseguido en su huida; pero podría ocurrir también que aquél hubiera logrado ocultarse momentáneamente mientras es perseguido. Y, por ende, cuando acude la policía, intervendría en la persecución, únicamente a partir de las descripciones físicas y/o de vestimenta del perseguido, que hubieran indicado quienes la iniciaron. Obvio es que debe, en este caso, tenerse sumo cuidado para no afectar a terceros inocentes. El hecho ilícito en sí, respecto del cual no hay inmediatez, sino cierta cercanía, debe haber tenido lugar en un tiempo anterior próximo razonable.

El tema de la continuidad de la persecución en el espacio y tiempo también puede presentarse complejo en el caso de la flagrancia material, pero puede ser resuelto, a nuestro entender, orientándonos por la razonabilidad. En estos casos, subsisten los temas del tiempo y de la "no pérdida de vista" de la persona del perseguido.

Finalmente, el Tribunal Constitucional peruano ha apuntado lo siguiente: "Según lo ha establecido este Tribunal en reiterada jurisprudencia, la flagrancia en la comisión de un delito, presenta 2 requisitos insustituibles: a) la inmediatez temporal, es decir, que el delito se esté cometiendo o que se haya cometido instantes antes; b) la inmediatez personal, que el presunto delincuente se encuentre ahí, en ese momento en situación y con relación al objeto o a los instrumentos del delito, que ello ofrezca una prueba evidente de su participación en el hecho delictivo.

En tal sentido del estudio de autos se advierte que el beneficiario fue capturado a las 23.15 horas del día 3 de abril de 2004, en inmediaciones de la plazuela 21 de abril, en circunstancias en que se encontraba próximo a la comisaría del sector, luego de una intervención policial realizada en su domicilio a las 22.50 horas de ese mismo día, diligencia que se llevó a cabo en presencia de fiscal; en la que se encontró droga y durante la cual se dio a la fuga por el techo de su casa, concordante con la declaración explicativa de fs. 21. De lo cual se colige que, en el presente caso, no hubo comisión flagrante de delito, toda vez que la flagrancia supone la aprehensión del autor de la infracción en el preciso momento de la comisión del mismo o que durante la aprehensión al autor se encuentre con el objeto o los instrumentos del delito.

Por el contrario, del acta de la sumaria investigación obrante en autos, se llega a establecer que la detención del favorecido se produjo en momento posterior al de la presunta comisión del delito de tráfico ilícito de drogas, esto es, en las cercanías de la comisaría del sector que tuvo a su cargo el operativo policial, realizado con la finalidad de erradicar la microcomercialización de drogas". ${ }^{45}$

\footnotetext{
${ }^{45}$ Tribunal Constitucional del Perú. Delgado con Primera Sala Penal de la Corte Superior de Justicia del Santa (2004).
} 
- La flagrancia evidencial. Se constituye por la presencia de evidencias materiales inobjetables que vinculan a una persona con la comisión de un hecho ilícito, respecto del cual existe proximidad temporal significativa.

En este caso, lo que se aprecia es la aparición de datos indiciarios objetivos que constituyen, para una persona media de nuestra sociedad, motivos racionalmente suficientes para terminar pensando que nos hallamos ante el autor de un ilícito temporalmente próximo (no acontecido hace mucho).

Aquí, debe distinguirse que el caso paradigmático importará la observación inmediata, a simple vista, de los indicios claros de vínculo con el delito, lo cual justificará la inmediata detención. Consideramos que una sospecha puede motivar a que el policía solicite la colaboración del sospechoso, en el esclarecimiento de los cargos, mas no podrá justificar la detención. Cuando se presentan denuncias anónimas por hechos muy recientes, puede ocurrir que se ofrezcan datos que pueden constituir un caso de flagrancia evidencial. Aquí lo relevante será el tiempo transcurrido desde la comisión del ilícito. Obviamente si hubieran transcurrido varios días, ya no podría efectuarse una detención, pues sólo forzadamente podría hablarse de flagrancia.

El caso de la aparición de huellas o indicios de la comisión de un ilícito en la persona o cosas del presunto autor nos lleva a entender e incluir este caso en la flagrancia evidencial. Tal género de huellas ha sido considerado en Chile, donde se hace referencia a "señales en sí mismo o en sus vestidos" (Paillas, 1986, p. 48).

Elementos identificables pueden darse varios, aunque no necesariamente todos a la vez: a) atribución de la autoría por un agraviado o terceros; b) actitud fundadamente sospechosa; c) la aparición de objetos materiales que le vincularían a la comisión del ilícito penal; d) proximidad razonable de la comisión del delito.

Finalmente, el Tribunal Constitucional peruano ha establecido lo siguiente: "Según lo ha establecido este Tribunal en reiterada jurisprudencia, la flagrancia en la comisión de un delito presenta 2 requisitos insustituibles: a) la inmediatez temporal, es decir, que el delito se esté cometiendo o que se haya cometido instantes antes; b) la inmediatez personal, esto es, que el presunto delincuente se encuentre ahí, en ese momento en situación; y con relación al objeto o a los instrumentos del delito, que ello ofrezca una prueba evidente de su participación en el hecho delictivo (Cfr. STCs. Exp. No 2096-2004-HC/TC, caso Eleazar Camacho Fajardo; Exp. No 06646-2006-PHC/TC, caso Alberto Gonzalo Vega Sánchez; Exp. No 6142-2006-PHC/TC, caso James Yovani Rodríguez Aguirre)”. ${ }^{46}$

\footnotetext{
${ }^{46}$ Tribunal Constitucional del Perú. Hilario con Segunda Sala Especializada en lo Penal para procesos con reos libres de la Corte Superior de Justicia de Lima (2008).
} 


\section{B. Temporalidad}

En el Perú, la detención policial de acuerdo con nuestra norma constitucional no puede durar más de veinticuatro horas. Dice la Carta Magna que el detenido debe ser puesto a disposición del juzgado correspondiente, dentro de las veinticuatro horas o en el término de la distancia. A diferencia de otras constituciones, el tiempo asignado para la detención policial resulta bastante breve, lo que importa la necesidad de poner al detenido y los hechos en se funda la detención a conocimiento del Juez Penal, a fin de que determine la situación jurídica de libertad o de mantenimiento de la detención.

Se trata de un término común, es decir, se computan las 24 horas entre la detención de una persona por la policía y la puesta a disposición del Juez, lo que supone que la investigación, la elaboración del atestado correspondiente y la puesta a disposición primero de la Fiscalía debe realizarse en un tiempo que no supere al señalado. Tanto en la policía como en el Ministerio Público y en el Juzgado se ha de respetar escrupulosamente dicho término; para ello resulta de mucha utilidad la boleta de detención que debe ser entregada al detenido y cuya copia debe aparecer en el atestado policial.

\subsubsection{La detención efectuada por particulares}

Por exclusión, particular será aquella persona que no ostenta la condición de autoridad o agente de la Policía, o aquel que siéndolo no interviene en el ejercicio de su cargo y en su ámbito competencial (De Hoyos, 1998, p. 70).

Por otra parte, no sólo el particular ofendido por el delito puede practicar la detención; podrá intervenir cualquiera, independientemente de su edad, bastará con que fácticamente sea capaz de efectuarla.

Según Schubert, el estudio histórico de la configuración de la medida de la detención por particulares antes de la asunción por el Estado de la tarea de la persecución de los delitos, resulta en escasa medida revelador de la función que en la actualidad desempeña este tipo de detenciones, pues la naturaleza de estas privaciones de libertad cambió sustancialmente, considerándose desde ese momento exclusivamente como un apoyo a la actuación de los órganos de la persecución penal del Estado.

Se afirma hoy que la detención efectuada por los particulares sólo tiene una función de complemento de la actuación, en este ámbito, de la Policía, por lo que sólo intervendrán cuando no puedan hacerlo éstas. De tal característica se deduce, además, la obligación de poner el detenido inmediatamente a disposición de la autoridad más cercana. 
En esa inteligencia, la actuación del particular en la detención de otro ciudadano es un derecho o facultad; por lo tanto, en ningún caso puede estar obligado a realizar una acción de este tipo, que por otra parte puede entrañar riesgos para la persona o bienes del que la realiza o de terceros, quedando la decisión última en manos del particular, pues la persecución de los delitos es una actividad que se encomienda a los órganos del Estado.

La intervención del particular procede cuando las autoridades que tienen constitucionalmente encomendada la persecución de los delitos no pueden actuar. De esta manera, si los órganos del Estado se encuentran en el lugar en que presuntamente se ha cometido un hecho delictuoso y no llevan a cabo la detención, por no ser procedente, no podrá hacerlo el particular. Esto no quiere decir que la facultad de detener de los particulares sea subsidiaria, es decir, no es necesario que antes de proceder a la detención los particulares traten de localizar a la Policía -salvo, si pudiera hacerse rápidamente y sin complicaciones- para que sean ellos los que efectúen dicha medida. Si así fuera el interés del Estado y, en general, el interés supraindividual en la persecución del delito quedaría innecesariamente frustrado.

En suma, para que un particular pueda detener a una persona por concurrir una situación de flagrancia, es necesario que haya apreciado a través de los sentidos la comisión de un delito, bien la totalidad o una parte del proceso de ejecución del acto delictivo, o al menos la producción ya consumada de un delito que tuvo lugar instantes antes, siempre y cuando en este caso exista conexión material directa e inmediata -huellas, instrumentos- entre el hecho producido y la persona o personas a quienes se imputa su comisión, de tal forma que tales circunstancias evidencien su participación en el hecho punible.

\subsubsection{Criterios para evaluar la constitucionalidad de una detención en situación de flagrancia delictiva}

Entre los criterios que pueden ayudar al Fiscal o al Juez para evaluar la detención de una persona en haber sido sorprendida en delito flagrante son:

1. Necesidad de intervención. El periculum libertatis, como presupuesto necesario para adoptar una medida cautelar personal en el proceso penal, lo constituye en este caso el peligro de fuga o de ocultación personal del imputado, y podemos cuantificarlo en virtud de la gravedad del hecho delictivo cometido y por las circunstancias personales y sociales del imputado, de tal forma que una apreciación conjunta de estos datos pueda hacer presumir racionalmente que el imputado intentará sustraerse a la acción de la justicia (De Hoyos, 1998, p. 91). 
En ese orden de ideas, al ser la flagrancia un presupuesto fáctico que permite la limitación de derechos fundamentales sin el previo mandamiento judicial, se debe exigir la existencia de una necesidad urgente de intervenir para evitar la fuga u ocultación del imputado y, si fuese posible, impedir que prosiga la afectación de un bien jurídico.

2. Proporcionalidad. Si bien es una condición necesaria, no es suficiente que exista una base legal para poder invadir la esfera correspondiente a la libertad individual del imputado. Tampoco resulta bastante para poder acordar una medida cautelar privativa de libertad como es la detención, la presencia en el caso concreto de un fumus commisi delicti y del periculum libertatis. Es preciso dar un paso más en el análisis de los presupuestos necesarios para la adopción de la medida cautelar personal y afirmar que la norma que permite tal intromisión debe ser interpretada y aplicada a través del prisma del principio de proporcionalidad y, en todo caso, siempre de forma restrictiva.

Este principio supone, concretamente en esta fase del proceso penal, que la medida coercitiva que se adopte ha de ser, en primer lugar, adecuada o apta para alcanzar el objetivo constitucionalmente prefijado; en segundo lugar, tal medida debe ser necesaria, de tal forma que el fin pretendido no pueda ser cumplido a través de un medio menos gravoso para el sujeto pasivo de la medida; además, la carga que se impone a su destinatario ha de estar en razonable relación con las ventajas que se derivan por la consecución del fin deseado.

$\mathrm{Al}$ respecto, el Tribunal Constitucional del Perú ha indicado lo siguiente: "La medida de encarcelamiento ha sido instituida, prima facie, como una fórmula de purgación de pena por la comisión de ilícitos penales de determinada gravedad. En tal sentido, su aplicación como medida cautelar en aras de asegurar el adecuado curso de las investigaciones y la plena ejecutabilidad de una eventual sentencia condenatoria, debe ser la última ratio por la que puede optar un juez para asegurar el éxito del proceso penal.

Tal como establece el artículo 9 No 3 del Pacto Internacional de Derechos Civiles y Políticos, '(...) la prisión preventiva de las personas que hayan de ser juzgadas no debe ser la regla general'. Lo propio queda expuesto en la regla 6.1 de las denominadas Reglas Mínimas de las Naciones Unidas sobre las medidas privativas de la libertad (Reglas de Tokio), que precisa que: 'sólo se recurrirá a la prisión preventiva como último recurso'. Asimismo, la Comisión Interamericana de Derechos Humanos ha subrayado: '(...) la detención preventiva es una medida excepcional y que se aplica solamente en los casos en que haya una sospecha razonable de que el acusado podrá evadir la justicia, obstaculizar la investigación preliminar intimidando a los testigos, o destruir evidencia. Se trata de una medida 
necesariamente excepcional en vista del derecho preeminente a la libertad personal y el riesgo que presenta la detención preventiva en lo que se refiere al derecho a la presunción de inocencia y las garantías de debido proceso legal, incluido el derecho a la defensa'. (Informe No 12/96, párrafo 84)". ${ }^{47}$

Por otra parte, el principio de proporcionalidad opera en dos momentos o ámbitos distintos: al determinar si procede practicar la detención, por una parte, y en lo relativo a los medios a emplear para efectuar la misma. Como resume Naucke, es aplicable al decidir el sí y el cómo (De Hoyos, 1998, p. 94).

La pauta de la proporcionalidad debe hacer posible que en el caso concreto se adopte la medida cautelar de la detención por ser la más adecuada para lograr el fin constitucionalmente pretendido: evitar la afectación del bien jurídico y asegurar la presencia del imputado ante las autoridades encargadas de la persecución penal, por ser en ese supuesto la que restrinja en menor medida los derechos del sujeto pasivo, y por estar sus presupuestos en razonable relación con la finalidad deseada.

Por tanto, siempre que la detención sea acordada al margen de la pauta de proporcionalidad, carecerá de justificación razonable, será incompatible con la presunción de inocencia y dejará de ser propiamente una medida cautelar, pasando a tener carácter punitivo en cuanto al exceso.

\section{REFERENCIAS BIBLIOGRÁFICAS}

Alonso Pérez, Francisco (2003): Medios de investigación en el proceso penal (2a edición, editorial Dykinson, Madrid, p. 672).

Angulo Arana, Pedro Miguel (2002): "La detención en casos de flagrancia”, en Revista Actualidad Jurídica (Tomo 106), pp. 101-111.

Arias Eibe, Manuel José (2001): "La inviolabilidad del domicilio: dimensión constitucional y protección penal”, en Revista La Ley ( $\mathrm{No}^{\circ} .5327$ y 5328), pp. 1643-1668.

Balaguer Callejón, Francisco (1992): Fuentes del derecho (editorial Tecnos, Madrid, dos tomos).

Beltrán Núñez, Arturo (1995): "Entrada y registro en lugar cerrado e intervención de libros, papeles y comunicaciones", en A.A.V.V. Comentarios a las Leyes Procesales Militares (Madrid, Secretaría General Técnica del Ministerio de Defensa, pp. 1578-1680).

\footnotetext{
${ }^{47}$ Tribunal Constitucional del Perú. Berrocal con Sala Penal de la Corte Superior de Justicia de Huaura (2004).
} 
Bernal Pulido, Carlos (2003): El principio de proporcionalidady los derechos fundamentales (Centro de Estudios Políticos y Constitucionales, Madrid, p. 871). Betegon, Jerónimo, Gascón, Marina, De Páramo, Juan Ramón, Prieto, Luis (1997): Lecciones de teoría del derecho (Editorial McGraw-Hill, Madrid, p. 408).

Castañeda Otsu, Susana Ynes (2005): "El proceso de hábeas corpus en el Código Procesal Constitucional”, en A.A.V.V. Introducción a los procesos constitucionales. Comentarios al Código Procesal Constitucional (Lima, Jurista Editores), pp. 89102.

Castillo Córdoba, Luis (2003): Elementos de una teoría general de los derechos constitucionales (ARA Editores, Lima, p. 242).

CASTILLO CóRdOBA, Luis (2004): Habeas corpus, amparo y habeas data (ARA Editores, Lima, p. 403).

Cordero, Franco (2000): Procedimiento penal (editorial Temis, Bogotá, dos tomos).

De Peray Bariés, Alicia (2006): "La diligencia de entrada y registro en lugar cerrado", en A.A.V.V. La actuación de la Policía judicial en el proceso penal (Madrid, editorial Marcial Pons), pp. 158-167.

Eguiguren Praeli, Francisco (2002): Estudios constitucionales (ARA Editores, Lima, p. 570).

Espinosa - SaldaÑa BarRera, Eloy (2003): Jurisdicción Constitucional, impartición de justicia y debido proceso (ARA Editores, Lima, p. 476).

Fernández Sessarego, Carlos (1994): El derecho como libertad: Preliminares para una filosofia del derecho (2a edición, Universidad de Lima, Lima, p. 168).

GarCía Morillo, Joaquín (1995): El derecho a la libertad personal. Detención, privación y restricción de libertad (editorial Tirant lo Blanch, Valencia, p. 272).

Gimeno Sendra, José Vicente (1996): "Las intervenciones telefónicas en la jurisprudencia del Tribunal Constitucional y Supremo", en Revista La Ley (No 2), pp. 1617-1624.

Gimeno Sendra, Vicente, Cortés Domínguez, Valentín, Moreno Catena, Víctor Manuel (1997): Derecho procesal penal (2a edición, editorial Colex, Madrid, p. 996).

HÄBERLE, Peter (1997): La libertad fundamental en el estado constitucional (Pontificia Universidad Católica del Perú, Lima, p. 432).

JASPERS, Karl (1933): Ambiente espiritual de nuestro tiempo (editorial Labor, Barcelona, p. 208). 
JiMÉNEZ MAYOR, Juan (2000): Jurisprudencia en materia constitucional. Selección, clasificación y comentarios (Consejo de Coordinación Judicial, Lima, p. 384).

López-Fragoso Álvarez, Tomás (1991): Las intervenciones telefónicas en el proceso penal (editorial Colex, Madrid, p. 172).

Magro Servet, Vicente (2002): "Casuística sobre el concepto penal de domicilio en la diligencia de entrada y registro", en Revista La Ley (No 5479), pp. 17641771.

Majada Planelles, Arturo (1990): Práctica procesal penal, procedimiento abreviado, disposiciones generales ( 5 a edición, editorial Bosch, Barcelona, dos tomos).

Marchal Escalona, Antonio Nicolás (2003): El atestado. Inicio del proceso penal (4a edición, editorial Aranzadi, Madrid, p. 550).

Martínez Pérez, Roberto (2001): La policía judicial y constitución (editorial Aranzadi, Madrid, p. 538).

Medina Guerrero, Manuel (1996): La vinculación negativa del legislador a los derechos fundamentales (editorial McGraw-Hill, Madrid, p. 180).

Momethiano Santiago, Javier Ysrael (2001): Derecho procesal penal (editorial Fecat, Lima, p. 651).

Oré Guardia, Arsenio (1999): Manual de Derecho Procesal Penal (editorial Alternativas, Lima, p. 335.

Ortells Ramos, Manuel (1978): "Para una sistematización de las medidas cautelares en el proceso penal”, en Revista General de Legislación y Jurisprudencia (No 244), pp. 439-489.

Palacios Criado, María Teresa (1998): "Diligencias que afectan a derechos fundamentales", en Cuadernos de Derecho Judicial (No 3), pp. 237-282.

Paz Rubio, José María, Mendoza Muñoz, Julio, Rodríguez Moriche, Rosa, OlLÉ SESÉ, Manuel (1999): La prueba en el proceso penal: su práctica ante los tribunales (editorial Colex, Madrid, p. 394).

Peces-Barba Martínez, Gregorio (1995): Curso de derechos fundamentales. Teoría general (Boletín Oficial del Estado, Madrid, p. 722).

Pérez Luño, Antonio (2003): Derechos humanos, estado de derecho y constitución (8 edición, editorial Tecnos, Madrid, p. 664).

Pérez Royo, Javier (2000): Curso de derecho constitucional (editorial Marcial Pons, Madrid, p. 1123).

Queralt, Joan Josep, JimÉnEZ Quintana, Elena (1987): Manual de policía judicial (Ministerio de Justicia, Madrid, p. 175).

Requena López, Tomás (2004): El principio de jerarquía normativa (editorial Civitas, Madrid, p. 359). 
Rodríguez Ramos, Luis, González Cuéllar, Antonio, Puente, Leopoldo, Paz Rubio, José María, González Cuéllar, Nicolás (2003): Comentarios a la ley de enjuiciamiento criminal y ley del jurado (13a edición, editorial Colex, Madrid, p. 1246).

Rodríguez Sol, Luis (1998): Registro domiciliario y prueba ilícita (editorial Comares, Granada, p. 342).

SÁnchez Velarde, Pablo (2004): Manual de derecho procesal penal (editorial Idemsa, Lima, p. 959).

San Martín Castro, César (1999): Derecho procesal penal (editorial Grijley, Lima, dos volúmenes).

SARTRE, Jean Paul (1947): El existencialismo es un humanismo (editorial Sur, Buenos Aires, p. 128).

ZafFaroni, Eugenio Raúl (2009): Estructura básica del derecho penal (editorial Ediar, Buenos Aires, p. 290).

\section{Sentencias del Tribunal Constitucional del Perú}

Townsend con Sala Corporativa Transitoria Especializada en Derecho Público de la Corte Superior de Justicia de Lima (1998): Tribunal Constitucional 17 abril 1998 (amparo) en: Gaceta Constitucional, formato electrónico. Disponible en: http:/www.tc.gob.pe/jurisprudencia/1998/01257-1997-AA.html

Silva con Segunda Sala Penal Corporativa para procesos ordinarios con reos libres de la Corte Superior de Justicia de Lima (2002): Tribunal Constitucional 12 agosto 2002 (hábeas corpus) en: Gaceta Constitucional, formato electrónico. Disponible en: http://www.tc.gob.pe/jurisprudencia/2002/01091-2002-HC.html Berrospi con Quinta Sala Civil de la Corte Superior de Justicia de Lima (2003): Tribunal Constitucional 29 enero 2003 (amparo) en: Gaceta Constitucional, formato electrónico. Disponible en: http://www.tc.gob.pe/jurisprudencia/2003/028632002-AA.html

Borea con Congreso de la República del Perú (2003): Tribunal Constitucional 10 diciembre 2003 (Proceso de inconstitucionalidad contra el documento denominado Constitución Política del Perú de 1993) en: Gaceta Constitucional, formato electrónico. Disponible en: http://www.tc.gob.pe/ jurisprudencia/2003/00014-2003-AI.html

Villanueva con Segunda Sala Penal Superior con reos libres de la Corte Superior de Justicia de Lima (2004): Tribunal Constitucional 16 abril 2004 (hábeas corpus) en: Gaceta Constitucional, formato electrónico. Disponible en: http://www. tc.gob.pe/jurisprudencia/2005/00731-2004-HC.html 
García con Sexta Sala Civil de la Corte Superior de Justicia de Lima (2004): Tribunal Constitucional 18 agosto 2004 (amparo) en: Gaceta Constitucional, formato electrónico. Disponible en: http://www.tc.gob.pe/jurisprudencia/2004/010582004-AA.html

Berrocal con Sala Penal de la Corte Superior de Justicia de Huaura (2004): Tribunal Constitucional 23 noviembre 2004 (hábeas corpus) en: Gaceta Constitucional, formato electrónico. Disponible en: http://www.tc.gob.pe/ jurisprudencia/2004/02915-2004-HC.html

Delgado con Primera Sala Penal de la Corte Superior de Justicia del Santa (2004): Tribunal Constitucional 27 diciembre 2004 (hábeas corpus) en: Gaceta Constitucional, formato electrónico. Disponible en: http://www.tc.gob.pe/ jurisprudencia/2005/02096-2004-HC.html

Anicama con Cuarta Sala Civil de la Corte Superior de Justicia de Lima (2005): Tribunal Constitucional 08 julio 2005 (amparo) en: Gaceta Constitucional, formato electrónico. Disponible en: http://www.tc.gob.pe/jurisprudencia/2005/014172005-AA.html

Chávez con Segunda Sala Penal de la Corte Superior de Justicia de Ica (2005): Tribunal Constitucional 19 mayo 2005 (hábeas corpus) en: Gaceta Constitucional, formato electrónico. Disponible en: http://tc.gob.pe/jurisprudencia/2006/025102005-HC.html

31 congresistas con Congreso de la República del Perú (2005): Tribunal Constitucional 21 julio 2005 (proceso de inconstitucionalidad contra el Artículo único de la Ley No 28568) en: Gaceta Constitucional, formato electrónico. Disponible en: http://www.tc.gob.pe/jurisprudencia/2005/00019-2005-AI\%20Resolucion. html

Medina con Cuarta Sala Especializada en lo penal para procesos con reos libres de la Corte Superior de Justicia de Lima (2005): Tribunal Constitucional 17 octubre 2005 (hábeas corpus) en: Gaceta Constitucional, formato electrónico. Disponible en: http://www.tc.gob.pe/jurisprudencia/2006/06712-2005-HC.html

Sarmiento con Primera Sala Especializada en lo penal de la Corte Superior de Justicia de Lambayeque (2005): Tribunal Constitucional 04 diciembre 2005 (hábeas corpus) en: Gaceta Constitucional, formato electrónico. Disponible en: http:// www.tc.gob.pe/jurisprudencia/2006/04557-2005-HC.html

Mallma con Segunda Sala Especializada en lo penal para procesos con reos en cárcel de la Corte Superior de Justicia de Lima (2006): Tribunal Constitucional 17 enero 2006 (hábeas corpus) en: Gaceta Constitucional, formato electrónico. Disponible en: http://tc.gob.pe/jurisprudencia/2006/08815-2005-HC.html 
Yupanqui con Segunda Sala Mixta Descentralizada de La Merced (2006): Tribunal Constitucional 29 agosto 2006 (hábeas corpus) en: Gaceta Constitucional, formato electrónico. Disponible en: http://www.tc.gob.pe/ jurisprudencia/2006/09068-2005-HC.html

Carrión con Tercera Sala Penal de la Corte Superior de Justicia de La Libertad (2007): Tribunal Constitucional 14 marzo 2007 (hábeas corpus) en: Gaceta Constitucional, formato electrónico. Disponible en: http://www.tc.gob.pe/ jurisprudencia/2007/06142-2006-HC.html

Ruiz con Segunda Sala Penal de la Corte Superior de Justicia de Piura (2007): Tribunal Constitucional 7 noviembre 2007 (hábeas corpus) en: Gaceta Constitucional, formato electrónico. Disponible en: http://tc.gob.pe/ jurisprudencia/2008/02635-2007-HC.html

Victorio con Primera Sala Especializada en lo penal para procesos con reos libres de la Corte Superior de Justicia de Lima (2008): Tribunal Constitucional 23 octubre 2008 (hábeas corpus) en: Gaceta Constitucional, formato electrónico. Disponible en: http://www.tc.gob.pe/jurisprudencia/2008/03016-2007HC.html

Hilario con Segunda Sala Especializada en lo penal para procesos con reos libres de la Corte Superior de Justicia de Lima (2008) Tribunal Constitucional 31 octubre 2008 (hábeas corpus) en: Gaceta Constitucional, formato electrónico. Disponible en: http://www.tc.gob.pe/jurisprudencia/2008/01957-2008-HC.html

Bazán con Sala Penal de la Corte Superior de Justicia de Cañete (2008): Tribunal Constitucional 10 diciembre 2008 (hábeas corpus) en: Gaceta Constitucional, formato electrónico. Disponible en: http://www.tc.gob.pe/ jurisprudencia/2009/04085-2008-HC.html

Contreras con Quinta Sala Civil de la Corte Superior de Justicia de Lima (2009): Tribunal Constitucional 28 septiembre 2009 (amparo) en: Gaceta Constitucional, formato electrónico. Disponible en: http://www.tc.gob.pe/ jurisprudencia/2009/03901-2007-AA.html

\section{Corte Suprema de Justicia del Perú}

Fujimori con Estado peruano (2008): Sala Penal Especial de la Corte Suprema de Justicia 02 enero 2008 (proceso penal por delito de intervención de comunicaciones) en: Jurisprudencia del Poder Judicial del Perú, formato electrónico. Disponible en: http://www.pj.gob.pe/CorteSuprema/documentos /..\%5C..\%5CCorteSuprema\%5Cspe\%5CDocumentos\%5CEXPEDIEN TE_ACUMULADO_033-2003_070809_001.pdf 


\section{Corte Interamericana de Derechos Humanos}

Tristán con Panamá (2009): Corte Interamericana de Derechos humanos 27 enero 2009 (violación a los derechos humanos protegidos por la Convención Interamericana de Derechos Humanos) en: Casos de la Corte Interamericana de Derechos Humanos, formato electrónico. Disponible en: www.corteidh.or.cr/ docs/casos/articulos/seriec_193_esp.doc

\section{Sentencias del Tribunal Supremo español}

José Pablo con Audiencia Provincial de San Sebastián (1995): Sala de lo Penal del Tribunal Supremo de España 07 julio 1995 (tráfico ilícito de drogas) en: Fondo documental del Consejo General del Poder Judicial, formato electrónico. Disponible en: http://www.poderjudicial.es/search/doAction?action=contentp df\&databasematch $=$ TS\&reference $=3201446 \&$ links $=$ \&optimize $=20030808$

Ministerio Fiscal con Audiencia Provincial de Soria (1999): Sala de lo Penal del Tribunal Supremo de España 04 marzo 1999 (tráfico ilícito de drogas) en: Biblioteca jurídica on-line Bosch, formato electrónico. Disponible en: http:// sentencias.juridicas.com/index.php 